OPEN ACCESS

Edited by:

Markus A. Ruegg,

Universität Basel, Switzerland

Reviewed by:

Maaike Van Putten,

Leiden University Medical Center,

Netherlands

Stefano Carlo Previtali, San Raffaele Scientific Institute

(IRCCS), Italy

*Correspondence:

Kinga I. Gawlik

kinga.gawlik@med.lu.se

Received: 31 October 2019

Accepted: 26 March 2020

Published: 21 April 2020

Citation:

Gawlik KI and Durbeej M (2020) A

Family of Laminin a2 Chain-Deficient

Mouse Mutants: Advancing

the Research on LAMA2-CMD.

Front. Mol. Neurosci. 13:59.

doi: 10.3389/fnmol.2020.00059

\section{A Family of Laminin $\alpha 2$ Chain-Deficient Mouse Mutants: Advancing the Research on LAMA2-CMD}

\author{
Kinga I. Gawlik* and Madeleine Durbeej \\ Muscle Biology Unit, Department of Experimental Medical Science, Lund University, Lund, Sweden
}

The research on laminin $\alpha 2$ chain-deficient congenital muscular dystrophy (LAMA2CMD) advanced rapidly in the last few decades, largely due to availability of good mouse models for the disease and a strong interest in preclinical studies from scientists all over the world. These mouse models continue to provide a solid platform for understanding the LAMA2-CMD pathology. In addition, they enable researchers to test laborious, necessary routines, but also the most creative scientific approaches in order to design therapy for this devastating disorder. In this review we present animals belonging to the laminin $\alpha 2$ chain-deficient " $d y / d y$ " mouse family $\left(d y / d y, d y^{2 \mathrm{~J}} / d y^{2 \mathrm{~J}}, d y^{3 \mathrm{~K}} / d y^{3 \mathrm{~K}}, d y^{\mathrm{W}} / d y^{\mathrm{W}}\right.$, et al.) and a summary of the scientific progress they facilitated. We also raise a few questions that need to be addressed in order to maximize the usefulness of laminin $\alpha 2$ murine mutants and to further advance the LAMA2-CMD studies. We believe that research opportunities offered by the mouse models for LAMA2-CMD will continuously support our efforts to find a treatment for the disease.

Keywords: muscular dystrophy, laminin, transgene, knockout, basement membrane, animal model

\section{INTRODUCTION}

The use of animals for scientific purposes goes back to ancient Greece where philosophers and scientists such as Alcmaeon of Croton, Aristotle, and Erasistratus dissected animals for anatomical studies. Today, the use of animals is a general practice for studying human biology and disease as the genetic similarity between humans and mice is very high. Also, the rapid development of methods for creating genetically modified animals increases their scientific value and stimulates general interest in preclinical research in society. One of the mouse models for laminin $\alpha 2$ chaindeficiency, the spontaneous $d y / d y$ mutant, was described in 1955. It was the first reported mouse strain representing the pathological criteria that were characteristic for muscular dystrophy. The hereditary pattern of the defects suggested an autosomal recessive disorder and the causative mutation was called dystrophia muscularis, designated by the symbol $d y$ (Michelson et al., 1955). Understandably, at that time it was not linked to any specific inherited muscle disease but in 
1994 two independent research groups suggested that deficiency of laminin $\alpha 2$ chain might be the primary defect in $d y / d y$ mice (Sunada et al., 1994; Xu et al., 1994a). Yet, until this date the mutation in the Lama2 gene in the $d y / d y$ mouse has not been identified.

\section{OVERVIEW OF LAMA2-CMD MOUSE MODELS}

More than 300 mutations in the LAMA2 gene have been identified so far in patients (Oliveira et al., 2018), which result in a large clinical heterogeneity of the disease. Realistically, the whole range of human mutations cannot be mimicked in mice, but currently available mouse models mirror well the broad spectrum of the human LAMA2-CMD condition (Table 1). This creates an opportunity for more efficient preclinical testing and conclusive preclinical studies.

The three most commonly used animal models for LAMA2$\mathrm{CMD}$ are $d y^{2 \mathrm{~J}} / d y^{2 \mathrm{~J}}$ (Xu et al., 1994b; Sunada et al., 1995), $d y^{3 \mathrm{~K}} / d y^{3 \mathrm{~K}}$ (Miyagoe et al., 1997), and $d y^{\mathrm{W}} / d y^{\mathrm{W}}$ mice (Kuang et al., 1998b; Table 1 and Figure 1). Skeletal muscle and peripheral nerve are the tissues with the most evident pathology in LAMA2-CMD mutants (Yurchenco et al., 2017). The dystrophic symptoms and general muscle pathology at the advanced stages of the disease have been fairly well characterized in all three models (Xu et al., 1994b; Miyagoe et al., 1997; Kuang et al., 1998b; Moll et al., 2001; Guo et al., 2003; Girgenrath et al., 2004, 2009; Gawlik et al., 2010, 2018; Carmignac et al., 2011a; Kumar et al., 2011; Pasteuning-Vuhman et al., 2018). Yet, we still need to learn more about mechanisms driving the disease progression in mouse. Only recently the importance of the embryonic, pre-symptomatic stages and early pathogenesis in the different mouse models for LAMA2-CMD has been emphasized (Gawlik et al., 2014, 2019; Mehuron et al., 2014; Nunes et al., 2017; Moreira Soares Oliveira et al., 2018). Likewise, associated symptoms in non-muscle tissues (peripheral and central nervous system, cardiorespiratory system) have gained attention (Hager et al., 2005; Qiao et al., 2005, 2018; Yang et al., 2005; Gawlik et al., 2006a, 2018, Homma et al., 2011; Menezes et al., 2014; Willmann et al., 2017; Pasteuning-Vuhman et al., 2018; Rabie et al., 2019).

Below we present a concise overview of the pathology in the three mouse models.

\section{Phenotype of $d y^{2 \mathrm{~J}} / d y^{2 \mathrm{~J}}$ Mice}

$D y^{2 \mathrm{~J}} / d y^{2 \mathrm{~J}}$ mice carry a splice site mutation in the LN domain, which results in production of a shorter laminin $\alpha 2$ chain lacking the N-terminal portion of the molecule (Xu et al., 1994b; Sunada et al., 1995). The truncation hinders polymerization of laminin matrices and formation of basement membranes (Colognato and Yurchenco, 1999; Yurchenco et al., 2004; Yurchenco and Patton, 2009), but the phenotype of $d y^{2 \mathrm{~J}} / d y^{2 \mathrm{~J}}$ mice is relatively mild (Guo et al., 2003) (phenotype overview: Figures 1, 2 and Tables 2, 3). Their survival extends over 6 months of age (Xu et al., 1994b). Although the majority of dystrophic features are similar between $d y^{2 \mathrm{~J}} / d y^{2 \mathrm{~J}}$ males and females (dystrophic features in different muscle types) (Pasteuning-Vuhman et al., 2018), one has to take into consideration that gender-related phenotype differences (weight gain, creatine kinase levels (CK), water intake, muscle strength), exist in this mouse model (Fontes-Oliveira et al., 2018; Moreira Soares Oliveira et al., 2018; PasteuningVuhman et al., 2018), which thus far has not been demonstrated for other LAMA2-CMD mutants. While these differences do not impact the overall disease presentation (they are rather subtle and a more severe phenotype cannot be attributed to any gender), they could significantly influence the outcomes of therapeutic strategies (Fontes-Oliveira et al., 2018). Hence, analysis of the treatment effects in $d y^{2 \mathrm{~J}} / d y^{2 \mathrm{~J}}$ mice should take into account both genders separately.

The pre-symptomatic stages of the disease in the $d y^{2 \mathrm{~J}} / d y^{2 \mathrm{~J}}$ mouse have not been delineated. The earliest time-point analyzed is 3 weeks of age and at this stage $d y^{2 \mathrm{~J}} / d y^{2 \mathrm{~J}}$ animals show normal muscle strength and collagen content in muscle is not changed (Moreira Soares Oliveira et al., 2018). However, muscle damage has already taken place as demonstrated by elevated CK levels, pronounced inflammatory response and occurrence of regenerating fibers (Figure 2; Kemaladewi et al., 2018; Moreira Soares Oliveira et al., 2018). Additionally, 3-week-old $d y^{2 \mathrm{~J}} / d y^{2 \mathrm{~J}}$ males weigh less than wild-type male littermates. One week later, other dystrophic hallmarks (central nucleation, decreased muscle strength) are established and fully developed pathology can be observed at 6-8 weeks of age, including increased production of several extracellular matrix components, muscle atrophy and decreased body weights in both genders (Nevo et al., 2010; McKee et al., 2017; Fontes-Oliveira et al., 2018; Moreira Soares Oliveira et al., 2018; Tables 2, 3). Reduced muscle strength and mobility between 4-10 weeks of age has been clearly documented in several studies (Dadush et al., 2010; McKee et al., 2017; FontesOliveira et al., 2018; Gawlik et al., 2018; Moreira Soares Oliveira et al., 2018; Pasteuning-Vuhman et al., 2018). The follow-up of the $d y^{2 \mathrm{~J}} / d y^{2 \mathrm{~J}}$ mouse condition up to 34 weeks of age did not reveal significant muscle pathology progression compared to 6week-old mice (Pasteuning-Vuhman et al., 2018), except for the additional body weight loss between week 6-10 (Fontes-Oliveira et al., 2018). In contrary, the CK levels were normalized with age (Holmberg et al., 2014; Pasteuning-Vuhman et al., 2018) and challenging the mice with functional tests throughout the course of the disease (between week 6 and 34) did not worsen the dystrophic symptoms (Pasteuning-Vuhman et al., 2018). It is also important to mention that different muscles display variation in the severity of the phenotype (gastrocnemius and tibialis anterior are more affected than triceps; diaphragm shows mild pathology) and distinct patterns of pathology development (for example different timing and degree of inflammation) (Gawlik et al., 2018; Kemaladewi et al., 2018; Pasteuning-Vuhman et al., 2018).

Due to its prolonged survival time compared to other mouse models, the $d y^{2 \mathrm{~J}} / d y^{2 \mathrm{~J}}$ mouse is widely used for studies of peripheral neuropathy associated with laminin $\alpha 2$ chaindeficiency (Yang et al., 2005; Gawlik et al., 2018; Rabie et al., 2019). The first signs of peripheral neuropathy (hind limb clasping when lifted by tail) are visible 4 weeks after birth and aggravate with age. Temporary hind limb paralysis (symptoms ceasing and relapsing, often in one limb only) occurs already around week 6 and permanent hind limb paralysis by 3 months 
TABLE 1 | Summary of available LAMA2-CMD mouse models.

\begin{tabular}{|c|c|c|c|c|c|}
\hline Mouse & Mutation & Laminin $\alpha 2$ expression & Phenotype $^{\#}$ & Time of death & References \\
\hline$d y / d y$ & Spontaneous, unknown & $\begin{array}{l}\text { Reduced expression of normal } \\
\text { sized laminin } \alpha 2\end{array}$ & $\begin{array}{l}\text { Moderate } \\
\text { muscular dystrophy } \\
\text { Peripheral neuropathy }\end{array}$ & $\begin{array}{l}\text { Before } 6 \text { months of } \\
\text { age }\end{array}$ & $\begin{array}{l}\text { Sunada et al., } \\
\text { 1994; Xu et al., } \\
\text { 1994a }\end{array}$ \\
\hline$d y^{2 J} / d y^{2}$ & $\begin{array}{l}\text { Spontaneous splice site } \\
\text { mutation in LN domain }\end{array}$ & $\begin{array}{l}\text { Slightly reduced expression of } \\
\text { truncated laminin } \alpha 2 \text { missing } \\
\text { LN domain }\end{array}$ & $\begin{array}{l}\text { Mild muscular dystrophy } \\
\text { Peripheral neuropathy }\end{array}$ & $\begin{array}{l}\text { After } 6 \text { months of } \\
\text { age }\end{array}$ & $\begin{array}{l}\text { Xu et al., 1994b; } \\
\text { Sunada et al., } 1995\end{array}$ \\
\hline$d y^{6 \mathrm{~J}} / d y^{6 \mathrm{~J}}$ & Spontaneous, unknown & Unknown & $\begin{array}{l}\text { Moderate (?) muscular } \\
\text { dystrophy } \\
\text { Peripheral neuropathy }\end{array}$ & $\begin{array}{l}\text { Before } 6 \text { months of } \\
\text { age }\end{array}$ & $\begin{array}{l}\text { https://www.jax. } \\
\text { org/strain/003589 }\end{array}$ \\
\hline$d y^{7} \mathrm{~J} / d y^{7} \mathrm{~J}$ & $\begin{array}{l}\text { ENU-induced missense } \\
\text { mutation in LN domain }\end{array}$ & $\begin{array}{l}\text { Normal levels of normal sized } \\
\text { laminin } \alpha 2\end{array}$ & $\begin{array}{l}\text { Mild muscular dystrophy } \\
\text { Peripheral neuropathy }\end{array}$ & $\begin{array}{l}\text { After } 6 \text { months of } \\
\text { age }\end{array}$ & Patton et al., 2008 \\
\hline$d y^{W} / d y^{W}$ & Knock-out & $\begin{array}{l}\text { Severely reduced expression of } \\
\text { truncated laminin } \alpha 2 \text { missing } \\
\text { LN domain }\end{array}$ & $\begin{array}{l}\text { Severe muscular dystrophy } \\
\text { Peripheral neuropathy }\end{array}$ & $5-12$ weeks of age & $\begin{array}{l}\text { Kuang et al., } \\
\text { 1998b; Willmann } \\
\text { et al., } 2017\end{array}$ \\
\hline$d y^{3 \mathrm{~K}} / d y^{3 \mathrm{~K}}$ & Knock-out & Complete deficiency & $\begin{array}{l}\text { Very severe muscular dystrophy } \\
\text { Peripheral neuropathy }\end{array}$ & 3 weeks of age & $\begin{array}{l}\text { Miyagoe et al., } \\
1997\end{array}$ \\
\hline $\begin{array}{l}d y^{8 \mathrm{~J}} / d y^{8 \mathrm{~J}} \\
\text { (extinct) }\end{array}$ & Spontaneous, unknown & Unknown & $\begin{array}{l}\text { Severe (?) muscular dystrophy } \\
\text { Peripheral neuropathy }\end{array}$ & 3-4 weeks of age & $\begin{array}{l}\text { https://www.jax. } \\
\text { org/strain/009692 }\end{array}$ \\
\hline $\begin{array}{l}d y^{\mathrm{Pas}} / d y^{\mathrm{Pas}} \\
\text { (extinct) }\end{array}$ & $\begin{array}{l}\text { Spontaneous, } \\
\text { retrotransposal insertion } \\
\text { between exon } 34 \text { and } 35\end{array}$ & Complete deficiency & $\begin{array}{l}\text { Severe muscular dystrophy } \\
\text { Peripheral neuropathy }\end{array}$ & $\begin{array}{l}\text { Before } 13 \text { weeks of } \\
\text { age }\end{array}$ & Besse et al., 2003 \\
\hline
\end{tabular}

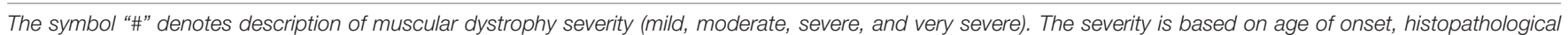

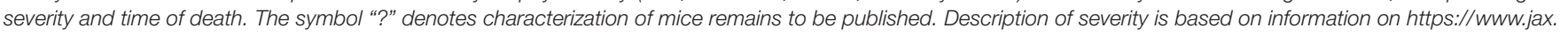
org/.
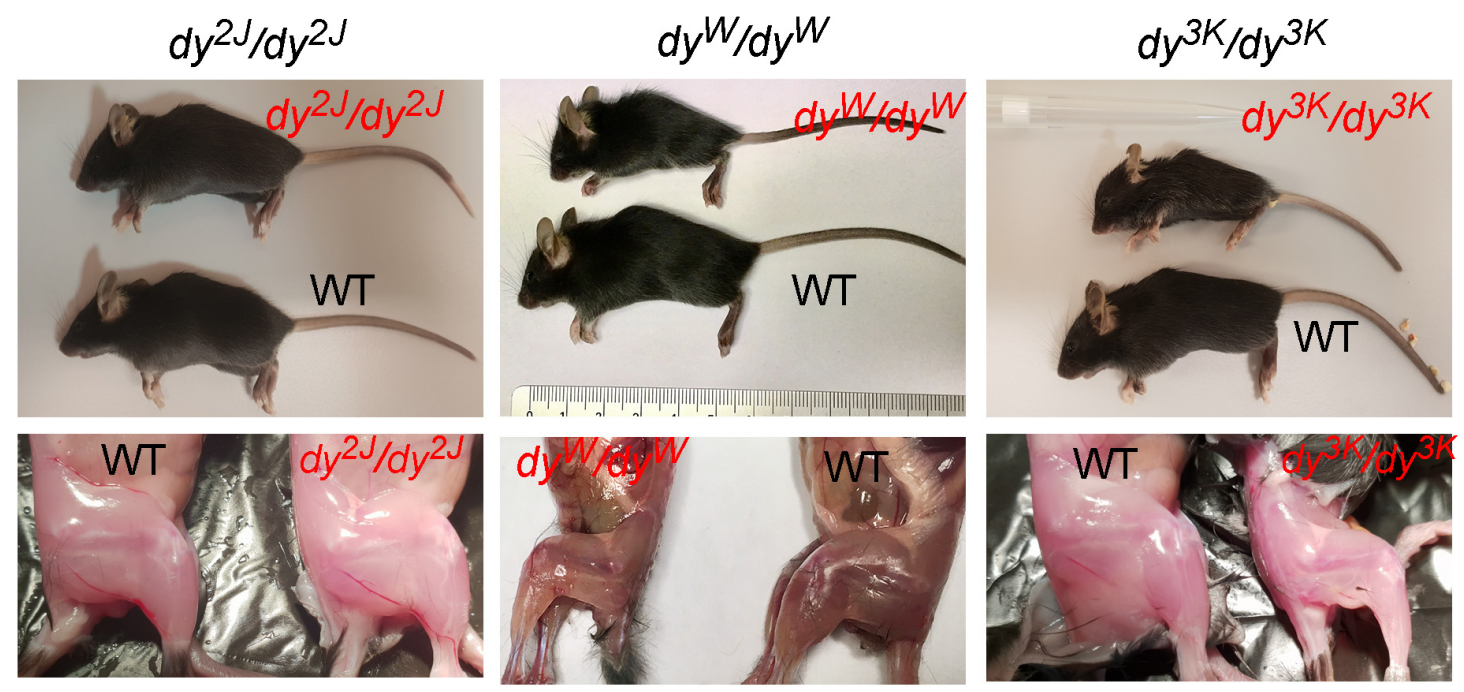

FIGURE 1 | General phenotype of dystrophic LAMA2-CMD mice $\left(d y^{2 \mathrm{~J}} / d y^{2 \mathrm{~J}}, d y^{\mathrm{W}} / d y^{\mathrm{W}}\right.$ and $\left.d y^{3 \mathrm{~K}} / d y^{3 \mathrm{~K}}\right)$ and their normal littermates (WT) at 3 weeks of age. Muscle wasting and weight loss are evident in $d y^{\mathrm{W}} / d y^{\mathrm{W}}$ and $d y^{3 \mathrm{~K}} / d y^{3 \mathrm{~K}}$ mice.

of age (Yang et al., 2005) (it is noteworthy that forelimbs, at least outwardly, are not affected). These symptoms are caused by impaired axonal sorting and dysmyelination (Yang et al., 2005; Gawlik et al., 2018), particularly in motor nerves (ventral roots), but also in dorsal roots (Yang et al., 2005; Rabie et al., 2019). Accordingly, motor nerve conduction velocity in the sciatic nerve is reduced (Domi et al., 2015; Rabie et al., 2019). It is important to mention that peripheral nerve defects cause neurogenic atrophy of muscle fibers (Gawlik et al., 2004; McKee et al., 2012) and contribute to dystrophic phenotype of skeletal muscle. Interestingly, although peripheral neuropathy is pronounced in all LAMA2-CMD mouse models (Guo et al., 2003), it is rarely manifested in patients (Yurchenco et al., 2017).

Respiratory function in $d y^{2 \mathrm{~J}} / d y^{2 \mathrm{~J}}$ mice has been assessed with the whole-body plethysmography. The respiratory rate and amplitude were significantly impaired in $d y^{2 \mathrm{~J}} / d y^{2 \mathrm{~J}}$ mice and the respiration rate further declined with age (Yu et al., 2013; Pasteuning-Vuhman et al., 2018). Cardiac manifestations are 

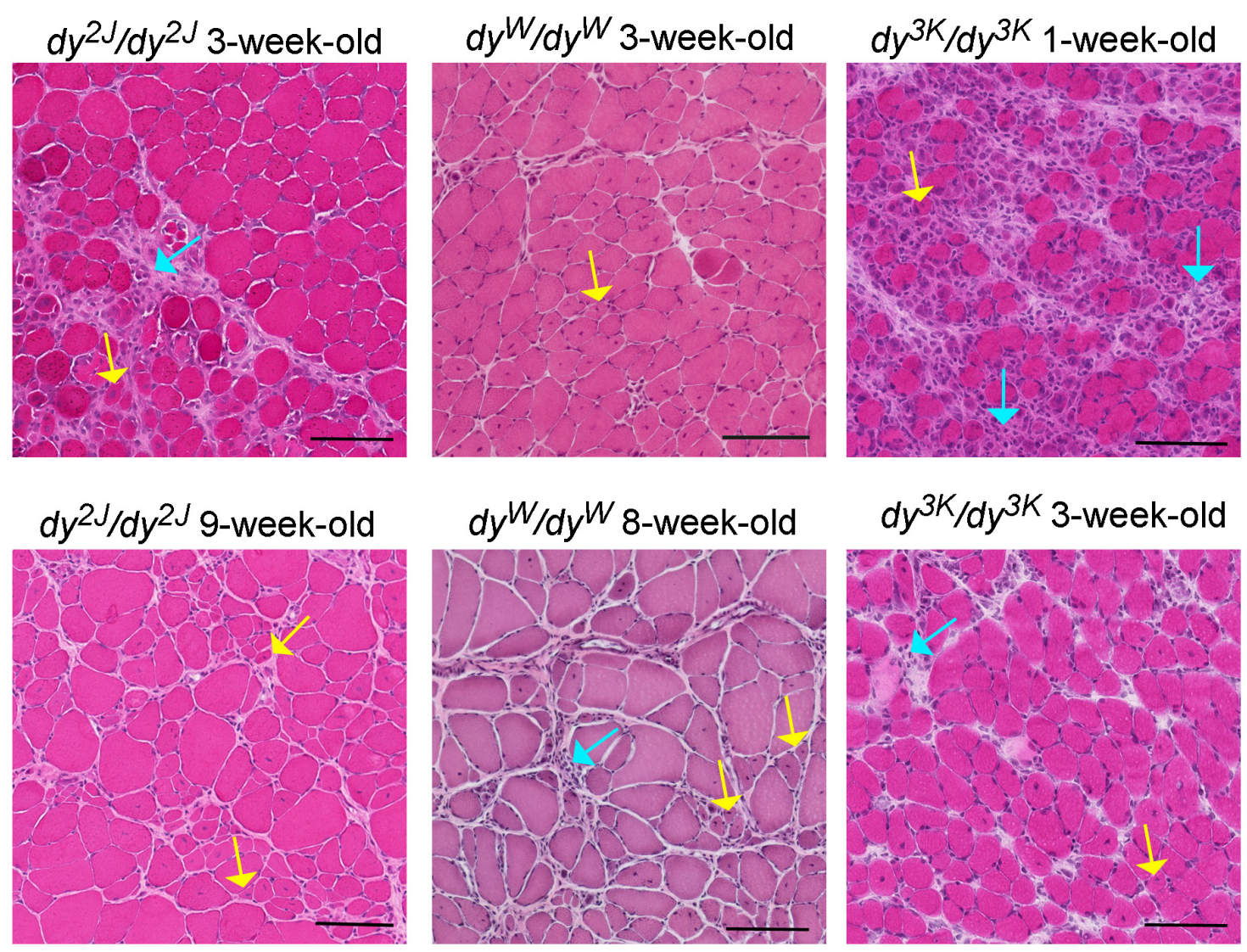

FIGURE 2 | Different stages of muscle pathology in three LAMA2-CMD mouse models ( $d y^{2} \mathrm{~J} / d y^{2 \mathrm{~J}}, d y^{\mathrm{W}} / d y^{\mathrm{W}}$, and $d y^{3 \mathrm{~K}} / d y^{3 \mathrm{~K}}$ ). Limb muscles (rectus femoris for $d y^{2 J} / d y^{2 J}$ and $d y^{3 \mathrm{~K}} / d y^{3 \mathrm{~K}}$, triceps for $d y^{\mathrm{W}} / d y^{\mathrm{W}}$ ) were stained with hematoxylin and eosin. Yellow arrows point to regenerating fibers with centrally located nuclei; turquoise arrows depict areas with inflammatory cells. Bars, $100 \mu \mathrm{m}$.

TABLE 2 | An overview of time-points describing the disease progress in LAMA-CMD mouse models $\left(d y^{2 J} / d y^{2 J}, d y^{\mathrm{W}} / d y^{\mathrm{W}}, d y^{3 \mathrm{~K}} / d y^{3 \mathrm{~K}}\right)$ based on muscle pathology.

\begin{tabular}{|c|c|c|c|c|}
\hline \multirow[b]{2}{*}{ Mouse model } & \multicolumn{4}{|c|}{ Disease progress (age) } \\
\hline & No symptoms & Onset & Early disease & Established disease \\
\hline$d y^{2 J} / d y^{2 J}$ & Time-point not determined & Time-point not determined & Week 3-4 & Week 6 onward \\
\hline$d y \mathrm{~W} / d y^{\mathrm{W}}$ & E10.5-E17 & E17.5-E18.5, smaller muscles & Week 1-2 & Week 3-15 \\
\hline$d y^{3 \mathrm{~K}} / d y^{3 \mathrm{~K}}$ & $\begin{array}{l}\text { E18.5 (earlier time-points } \\
\text { were not analyzed) }\end{array}$ & Postnatal day 1 , apoptosis & Week 1 & $\begin{array}{l}\text { Week 2-3, despite } \\
\text { improvements of muscle } \\
\text { morphology (plateau) }\end{array}$ \\
\hline
\end{tabular}

Onset: the first signs of muscle pathology. Early disease: muscle damage, inflammation and regeneration. Established disease: fibrosis, atrophy in addition to hallmarks mentioned earlier. Please note that only a few muscles were included in most of the studies and often a limited number of phenotyping methods was applied.

associated with some cases of LAMA2-CMD (mostly attributed to complete absence of laminin $\alpha 2$ chain) (Nguyen et al., 2019). Cardiomyopathy has not been observed in $d y^{2 \mathrm{~J}} / d y^{2 J}$ mice as assessed by histological means (8-week-old animals) (Gawlik et al., 2018) and echocardiography (12-15 and 3033 week-old animals) (Yu et al., 2013). Yet, the heart rates are increased in $d y^{2 J} / d y^{2 J}$ mutants (Yu et al., 2013) and hearts from 10-week-old dystrophic mice tend to weigh less (Fontes-Oliveira et al., 2018) than wild-type hearts. In the light of growing evidence that cardiac defects in patients (also with partial deficiency of laminin) could be underreported in literature (Nguyen et al., 2019), it is possible that histological features of cardiomyopathy may be manifested in hearts from older $d y^{2 J} / d y^{2 J}$ animals, despite no clear changes in electrophysiological parameters.

\section{Phenotype of $d y^{\mathrm{W}} / d y^{\mathrm{W}}$ Mice}

The $d y^{\mathrm{W}} / d y^{\mathrm{W}}$ mouse was generated by homologous recombination in embryonic stem cells and intended to represent the Lama2-null mutant (Kuang et al., 1998a,b). It was revealed later that the mouse is not completely devoid of laminin $\alpha 2$ chain, but shows strongly reduced expression of the truncated molecule 
TABLE 3 | A summary of the overall health and muscle phenotype of LAMA2-CMD mouse models $\left(d y^{2} \mathrm{~J} / d y^{2} \mathrm{~J}, d y^{\mathrm{W}} / d y^{\mathrm{W}}, d y^{3 \mathrm{~K}} / d y^{3 \mathrm{~K}}\right)$ at the different stages of development.

\begin{tabular}{|c|c|c|c|c|c|}
\hline \multirow[b]{2}{*}{ Mouse model } & \multicolumn{5}{|c|}{ Developmental stage } \\
\hline & Embryonic & $\begin{array}{l}\text { Neonatal, early } \\
\text { postnatal ( } 1-7 \text { day old) }\end{array}$ & Postnatal (1-3 week-old) & $\begin{array}{l}\text { Early adulthood (3-6 } \\
\text { week-old) }\end{array}$ & $\begin{array}{l}\text { Adulthood (older } \\
\text { than } 6 \text { weeks) }\end{array}$ \\
\hline$d y^{2 J} / d y^{2 J}$ & Not determined. & Not determined. & $\begin{array}{l}\text { Week 1-2 not determined. } \\
\text { Pronounced inflammation } \\
\text { and increased CK at } \\
\text { week } 3 .\end{array}$ & $\begin{array}{l}\text { Central nucleation, } \\
\text { inflammation, muscle fiber } \\
\text { size variation, weight loss, } \\
\text { CK variable, impaired } \\
\text { muscle function. } \\
\text { Phenotype clearly visible } \\
\text { outwardly. }\end{array}$ & $\begin{array}{l}\text { Fibrosis, central } \\
\text { nucleation, fiber size } \\
\text { variation. Impaired } \\
\text { neuromuscular function. }\end{array}$ \\
\hline$d y^{\mathrm{W}} / d y^{\mathrm{W}}$ & $\begin{array}{l}\text { Normal back muscle } \\
\text { morphology, smaller } \\
\text { muscle size from E18.5, } \\
\text { more detailed studies } \\
\text { needed. }\end{array}$ & $\begin{array}{l}\text { Smaller back muscles, } \\
\text { limb muscles normal size. } \\
\text { Morphology abnormalities, } \\
\text { apoptosis, inflammation. }\end{array}$ & $\begin{array}{l}\text { Atrophy (smaller limb } \\
\text { muscles, muscle fiber loss), } \\
\text { apoptosis, central } \\
\text { nucleation, inflammation, } \\
\text { fibrosis onset. Phenotype } \\
\text { clearly visible outwardly. }\end{array}$ & $\begin{array}{l}\text { Apoptosis, inflammation, } \\
\text { central nucleation, muscle } \\
\text { fiber loss, fibrosis, } \\
\text { increased CK, muscle } \\
\text { function impairment. }\end{array}$ & $\begin{array}{l}\text { Apoptosis, inflammation } \\
\text { muscle fiber loss, } \\
\text { atrophy, fibrosis, } \\
\text { increased CK, muscle } \\
\text { function impairment. }\end{array}$ \\
\hline$d y^{3 \mathrm{~K}} / d y^{3 \mathrm{~K}}$ & $\begin{array}{l}\text { Normal limb muscle, more } \\
\text { detailed studies needed. }\end{array}$ & $\begin{array}{l}\text { Apoptosis, muscle } \\
\text { degeneration, muscle fiber } \\
\text { loss, inflammation, central } \\
\text { nucleation, weight loss. } \\
\text { Phenotype clearly visible } \\
\text { outwardly. }\end{array}$ & $\begin{array}{l}\text { Muscle repair, atrophy } \\
\text { (smaller muscle fibers), } \\
\text { apoptosis, inflammation, } \\
\text { increased extracellular } \\
\text { matrix deposition. Impaired } \\
\text { motor function. } \\
\text { Abnormalities of masticatory } \\
\text { muscles. Increased CK, } \\
\text { death at week } 3 \text {. }\end{array}$ & $\begin{array}{l}\text { Currently NA (death at age } \\
\text { of } 3 \text { weeks). In previous } \\
\text { studies when } d y^{3 \mathrm{~K}} / d y^{3 \mathrm{~K}} \\
\text { mice survived up to } \\
5 \text { weeks: Apoptosis, } \\
\text { inflammation, central } \\
\text { nucleation, muscle fiber } \\
\text { loss, fibrosis, increased } \\
\text { CK, muscle function } \\
\text { impairment. }\end{array}$ & $\begin{array}{l}\text { NA (death at age of } \\
3 \text { weeks). }\end{array}$ \\
\hline
\end{tabular}

NA - not applicable.

(lacking the LN domain) (Guo et al., 2003). The phenotype is severe and $d y^{\mathrm{W}} / d y^{\mathrm{W}}$ mice die typically 5-12 weeks after birth (Kuang et al., 1998b) (phenotype overview: Figures 1, 2 and Tables 2, 3), but some do not survive post-weaning ${ }^{1}$.

Early timepoints of the disease pathology have been fairly well characterized in this mouse model (Mehuron et al., 2014; Nunes et al., 2017), including embryonic stages (E10.5-E18.5) (Nunes et al., 2017). In fact, myogenesis defects in utero have been pinpointed in $d y^{\mathrm{W}} / d y^{\mathrm{W}}$ mice (Nunes et al., 2017). While no obvious defects of muscle development have been demonstrated in LAMA2-CMD before (Kuang et al., 1998a; Gawlik and Durbeej, 2011), myofibers are smaller at birth and muscle degeneration/regeneration occurs shortly after birth in patients (Hayashi et al., 2001; Voit and Tome, 2004). Additionally, reduction of fetal movements has been reported (Jones et al., 2001). Hence, it is reasonable to consider muscle developmental abnormalities in LAMA2-CMD (even if they are subtle).

Although myotomal (E10.5), primary (E11.5-E13.5) and the first stages of secondary myogenesis (E14.5-E16.5) proceed normally in $d y^{\mathrm{W}} / d y^{\mathrm{W}}$ mice, the final stages of fetal myogenesis (E17.5-E18.5) are marked with a few abnormalities (studied in epaxial muscles). The developmental defects include decreased number of Pax7 and myogenin positive cells (secondary myogenesis, E17.5 onward), smaller muscles (E18.5 onward), which results in muscle growth impairment that is not recovered during postnatal development (Nunes et al., 2017; Tables 2, 3).

\footnotetext{
${ }^{1}$ https://www.jax.org/strain/013786
}

A few discrepancies concerning early postnatal development emerge from two separate studies: Nunes et al. (2017) reported no obvious morphology change in 2-day-old $d y^{\mathrm{W}} / d y^{\mathrm{W}}$ muscle, but alteration of muscle size (epaxial muscles), whereas Mehuron et al. (2014) observed morphology defects in 1-dayold muscle with clearly reduced number of myofibers, but no change in muscle size (tibialis anterior). This suggests that the characteristics of pathological events could differ between muscles and one has to be careful to draw generalized conclusions when studying one muscle. Accordingly, it has been shown in older mice that tibialis anterior is more affected than triceps (Reinhard et al., 2017), soleus and extensor digitorum (Vohra et al., 2015).

The natural history of the disease studied in $d y^{\mathrm{W}} / d y^{\mathrm{W}}$ limb muscles between 1 and 4-weeks of age reveals appearance of a broad range of dystrophic hallmarks (Figure 2 and Tables 2, 3. One-week old $d y^{\mathrm{W}} / d y^{\mathrm{W}}$ muscle is characterized with muscle fiber loss, extensive apoptosis, initiation of the inflammatory response together with the myogenic program as well as increased production of fibronectin, osteopontin and matrix remodeling proteins (Wardrop and Dominov, 2011; Mehuron et al., 2014). A decreased number of myofibers does not correlate with loss of body weight, muscle weight, and reduction of muscle size (Mehuron et al., 2014), although slight body weight differences between wild-type mice and $d y^{\mathrm{W}} / d y^{\mathrm{W}}$ mutants have been reported for 1-week-old animals in another study (Wardrop and Dominov, 2011). Upregulation of fibrillar collagens accompanies the pathology progression at week 2. Decrease in limb muscle 
weight coincides with the delay of the whole-body weight gain at week 3 (Mehuron et al., 2014). CK is significantly elevated in serum from 1-month-old $d y^{\mathrm{W}} / d y^{\mathrm{W}}$ mice (Kuang et al., 1998b) and fibrotic lesions are a signature of advanced pathology in $d y^{\mathrm{W}} / d y^{\mathrm{W}}$ muscle (Meinen et al., 2012; Accorsi et al., 2015; Accorsi et al., 2016). Interestingly, apoptosis is less pronounced in 3-4 week-old mice compared to younger mutants (Mehuron et al., 2014). Basement membranes have patchy appearance in $d y^{\mathrm{W}} / d y^{\mathrm{W}}$ muscle (Moll et al., 2001). The dystrophic changes described above correlate with impaired muscle function (Moll et al., 2001; Doe et al., 2011; Willmann et al., 2017).

Peripheral neuropathy is a prominent feature of the disease also in the $d y^{\mathrm{W}} / d y^{\mathrm{W}}$ mouse model (Kuang et al., 1998b), just like in all mouse models for LAMA2-CMD (Yurchenco et al., 2017). Several studies have explored the phenotype of peripheral nervous system in $d y^{\mathrm{W}} / d y^{\mathrm{W}}$ mutant, showing myelination defects in sciatic nerve and ventral roots, smaller cross sectional area of sciatic nerve, as well as motor dysfunction and sensorimotor gating deficits at age of 4-6 weeks (Homma et al., 2011; Qiao et al., 2018).

The respiratory function in $d y^{\mathrm{W}} / d y^{\mathrm{W}}$ mice has also been evaluated by whole-body plethysmography. However, the breath rate did not appear to change over time and may not be predictive of pathology in $d y^{\mathrm{W}} / d y^{\mathrm{W}}$ animals (Willmann et al., 2017). Analysis of cardiac muscle in this mouse model is required.

\section{Phenotype of $d y^{3 \mathrm{~K}} / d y^{3 \mathrm{~K}}$ Mice}

The $d y^{3 \mathrm{~K}} / d y^{3 \mathrm{~K}}$ mouse is the only available LAMA2-CMD mouse model void of laminin $\alpha 2$ subunit (Miyagoe et al., 1997; Guo et al., 2003). The complete loss of laminin $\alpha 2$ chain conceivably contributes to the most severe phenotype and much earlier death of the $d y^{3 \mathrm{~K}} / d y^{3 \mathrm{~K}}$ mouse compared to other models (currently 3 weeks of age, they used to survive up to 5 weeks, but their phenotype has gradually worsened over the years in our colony at Lund University) (phenotype overview: Figures 1, 2, Tables 2, 3, and Supplementary Video 1). The cause of death is most probably linked to malnutrition and respiratory difficulties (Gawlik et al., 2019).

No obvious development abnormalities have been detected in embryonic $d y^{3 \mathrm{~K}} / d y^{3 \mathrm{~K}}$ muscle (E18.5, calf muscles, thigh muscles) (Gawlik et al., 2019). Yet, more detailed studies are warranted in a wide range of muscles to confirm the current observations and comprehend myogenic events in $d y^{3 \mathrm{~K}} / d y^{3 \mathrm{~K}}$ embryos. Oneday-old $d y^{3 \mathrm{~K}} / d y^{3 \mathrm{~K}}$ muscles display normal morphology (fiber size, number of fibers). Inflammation and abnormal expression of the extracellular matrix components have not been detected. Yet, occasional occurrence of apoptotic fibers marks the pathogenesis onset in 1-day-old $d y^{3 \mathrm{~K}} / d y^{3 \mathrm{~K}}$ muscle (Gawlik et al., 2019). This suggests that $d y^{3 \mathrm{~K}} / d y^{3 \mathrm{~K}}$ muscles are prone to damage already at the neonatal stage, when the mouse movements are limited to sporadic limb waddling. Muscle damage progresses quickly and already 4-day-old muscles show inflammatory response to injury. At day 7 the body weight is significantly reduced coinciding with pronounced loss of muscle fibers and inflammation (Figure 2; Miyagoe et al., 1997; Gawlik et al., 2019). The extracellular matrix components are massively upregulated, which is associated with muscle repair. Importantly, the severe phenotype observed at day 7 is partially ameliorated with age: at day 14 and $21 d y^{3 \mathrm{~K}} / d y^{3 \mathrm{~K}}$ muscles show recovery of muscle fiber number, reduced inflammation (Figure 2) and downregulation of fibronectin and collagen III (Gawlik et al., 2019). Yet, apoptotic fibers and regenerating fibers are present at these stages (Miyagoe et al., 1997; Gawlik et al., 2019). Despite normalization of the number of myofibers, there is a decrease in fiber size and muscle mass (Carmignac et al., 2011a; Gawlik et al., 2019). Likewise, although the abundance of interstitial extracellular matrix is diminished in older mutants, the levels of collagen III and fibronectin remain elevated compared to a healthy agematched muscle (Table 3). CK levels are also increased in serum at that stage compared to wild-type mice (Gawlik et al., 2010; Holmberg et al., 2014). Basement membranes surrounding muscle fibers are discontinuous throughout the disease course (Miyagoe et al., 1997; Gawlik et al., 2004). Similarly to other LAMA2-CMD mouse models, $d y^{3 \mathrm{~K}} / d y^{3 \mathrm{~K}}$ limb muscles display variety of phenotype presentation: vastus lateralis, medialis, gastrocnemius are more affected than rectus femoris, triceps and tibialis anterior (Gawlik et al., 2019). However, one has to be aware that complete quantitative analyses of dystrophic features in a wide range of muscles over time are missing for all mouse models.

Interestingly, the muscle function tests performed on $d y^{3 \mathrm{~K}} / d y^{3 \mathrm{~K}}$ mice at different ages do not necessarily correlate with muscle phenotype. For example, 7 -day-old $d y^{3 \mathrm{~K}} / d y^{3 \mathrm{~K}}$ animals do not display significant difficulties when performing functional tests. On the contrary, 14-day-old mice show significant impairments of motor function (Gawlik et al., 2019).

Non-limb muscles have been studied in the $d y^{3 \mathrm{~K}} / d y^{3 \mathrm{~K}}$ mouse (Nystrom et al., 2006; Hager and Durbeej, 2009; Gawlik et al., 2014, 2019). The principal extraocular muscle and intrinsic laryngeal muscles appear spared (Nystrom et al., 2006; Hager and Durbeej, 2009), whereas accessory extraocular muscles show signs of myopathy (Gawlik et al., 2014). Esophagus shows mild muscular dystrophy (day 21); diaphragm, intercostal muscles, tongue, and temporalis demonstrate moderate dystrophic changes (studied at day 14 and 21). The most severe phenotype has been observed in masseter muscle (day 7, 14, and 21) (Gawlik et al., 2014, 2019).

Heart muscle has not been shown to be affected in $d y^{3 \mathrm{~K}} / d y^{3 \mathrm{~K}}$ mouse, based on histology analysis (Gawlik et al., 2004; Gawlik and Durbeej, 2015). It might be that $d y^{3 \mathrm{~K}} / d y^{3 \mathrm{~K}}$ animals die too early to develop cardiac manifestations. Alternatively, the presence of laminins containing laminin $\alpha 4$ chain that are expressed in $d y^{3 \mathrm{~K}} / d y^{3 \mathrm{~K}}$ heart (Durbeej lab, unpublished data) might be sufficient to prevent cardiomyopathy in laminin $\alpha 2$ chain deficient mice. However, it is not excluded that cardiac function could be impaired and this needs to be verified by electrophysiology studies.

It is interesting that death of $d y^{3 \mathrm{~K}} / d y^{3 \mathrm{~K}}$ mouse coincides with the improvement of limb muscle phenotype, which points toward severe defects in other tissues, importance of masticatory muscles for proper nutrition, and perhaps importance of respiration maintenance. Respiratory function is yet to be analyzed in $d y^{3 \mathrm{~K}} / d y^{3 \mathrm{~K}}$ mice. 
Demyelination of axons in sciatic nerve and in particular in ventral and dorsal roots, as well reduced size of axons (sciatic nerve) have been reported in $d y^{3 \mathrm{~K}} / d y^{3 \mathrm{~K}}$ mice (Nakagawa et al., 2001; Gawlik et al., 2006a). These defects result in reduced motor nerve conduction velocity of sciatic nerve (Nakagawa et al., 2001). Despite that, hind limb paralysis is not clearly manifested, probably due to early death of $d y^{3 \mathrm{~K}} / d y^{3 \mathrm{~K}}$ animals. Additionally, epilepsy episodes have been observed (Durbeej lab, unpublished observations).

\section{Other Mouse Models}

The moderately affected $d y / d y$ mouse expresses reduced amounts of full-length laminin $\alpha 2$ subunit (Sunada et al., 1994; Xu et al., 1994a). Patients showing a similar expression defect exist (Nissinen et al., 1996; Voit and Tome, 2004). Therefore, $d y / d y$ animals constitute an important addition to $d y^{2 J} / d y^{2 \mathrm{~J}}$, $d y^{3 \mathrm{~K}} / d y^{3 \mathrm{~K}}$, and $d y^{\mathrm{W}} / d y^{\mathrm{W}}$ murine models, especially because cardiomyopathy in $d y / d y$ mouse has been clearly demonstrated (fibrotic lesions at week 8, hypertrophic cardiomyopathy as evidenced by echocardiography at week 18) (Rash et al., 1998; Gawlik et al., 2010). Dy/dy mice live between 12 and 24 weeks (or longer), weigh much less already at the age of 3 weeks and remain very weak throughout the disease course (Connolly et al., 2001). They also display peripheral neuropathy (Matsumura et al., 1997). Initially this mouse model greatly facilitated experimental studies of the molecular pathology of the disease (Sunada et al., 1994; Xu et al., 1994a; Ringelmann et al., 1999). Unfortunately, the unidentified mutation makes the model more difficult to study (genotyping is not possible, which negatively impacts breeding strategies). Hence, the use of $d y / d y$ mice in research has diminished.

A point mutation (Arg to Cys) disrupting a conserved paired

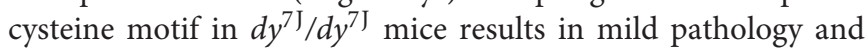
normal laminin $\alpha 2$ levels (Patton et al., 2008). In contrast to the other LAMA2-CMD mouse models, basement membrane is thickened in $d y^{7 \mathrm{~J}} / d y^{7 \mathrm{~J}}$ muscle and normal in peripheral nerve. Yet, muscle degeneration and severe amyelination of nerve roots affect the $d y^{7 \mathrm{~J}} / d y^{7 \mathrm{~J}}$ mouse (Patton et al., 2008). This mouse model provides opportunities to investigate underlying mechanisms and treatments for mild forms of LAMA2-CMD and to study additional factors that could play major roles in modulating laminin-related interactions in basement membrane

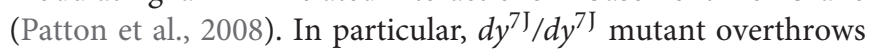
the dogma that the presence of basement membrane per se is necessary for prevention of the dystrophic phenotype.

Yet another mouse model, $d y^{6 \mathrm{~J}} / d y^{6 \mathrm{~J}}$, is available at Jackson Laboratories. The mutation remains to be identified but mice show progressive weakness and hind limb paralysis is visible at about 3 weeks of age ${ }^{2}$. Lastly, two nowadays extinct mouse models have also been described; $d y^{8 \mathrm{~J}} / d y^{8 \mathrm{~J}}$ and $d y^{\mathrm{Pas}} / d y^{\mathrm{Pas}}$. The former was identified at Jackson Laboratories ${ }^{3}$ and the latter spontaneously arose at the Pasteur Institute in Paris (Besse et al., 2003).

\footnotetext{
${ }^{2}$ https://www.jax.org/strain/003589

${ }^{3}$ https://www.jax.org/strain/009692
}

\section{MOLECULAR ASPECTS OF PATHOGENESIS STUDIED IN LAMA2-CMD MODELS}

It is difficult to study the pathogenesis of laminin $\alpha 2$ chaindeficiency in vivo in patients (ethical considerations, limited access to human material, large heterogeneity of patients). Mouse models for LAMA2-CMD help to overcome these obstacles and are excellent tools to explore molecular mechanisms of the disease. Over the years a tremendous amount of studies describing different aspects of the LAMA2-CMD pathology in mice has been collected. These include: (1) description of cellular and molecular events in laminin $\alpha 2$ chain-deficient muscle, (2) transgenic and gene therapy strategies to prevent the dystrophic phenotype (Table 4), (3) knockout strategies to prevent the dystrophic phenotype and/or understand the mechanisms of the disease (Table 5), and (4) pharmacological approaches to develop clinical treatment options (Table 6).

\section{Cellular and Molecular Events in Murine Laminin $\alpha 2$ Chain-Deficient Muscle}

Loss/reduction/truncation of laminin $\alpha 2$ subunit triggers secondary molecular changes in skeletal muscle. These changes lead to disruption of muscle homeostasis, but some of them may also constitute compensatory alterations. For example, a compensatory upregulation of laminin $\alpha 4$ and $\alpha 5$ subunits in LAMA2-CMD mouse models has been described (Ringelmann et al., 1999; Moll et al., 2001; Gawlik et al., 2004, 2018; McKee et al., 2017). Laminin $\alpha 4$ and laminin $\alpha 5$ chains do not bind equally well to $\alpha$-dystroglycan compared to laminin $\alpha 1$ and a2 subunits (Talts et al., 1999, 2000; Ferletta et al., 2003) and laminin $\alpha 4$ chain is also devoid of a domain that is essential for laminin polymerization (Yurchenco and Patton, 2009). Therefore, this upregulation only partially prevents a more acute disease progression (Voit and Tome, 2004). Ablation of laminin $\alpha 4$ in $d y^{3 \mathrm{~K}} / d y^{3 \mathrm{~K}}$ and $d y^{2 \mathrm{~J}} / d y^{2 \mathrm{~J}}$ mice apparently worsened the phenotype $\left(d y^{3 \mathrm{~K}} / d y^{3 \mathrm{~K}}\right.$ double mutant reported to die before 2 weeks of age) but the skeletal muscle phenotype remains to be characterized (Miner et al., 2004). Hence, the role of laminin $\alpha 4$ chain in LAMA2-CMD is not entirely clear. Yet, it is possible to enhance polymerization and muscle cell binding of compensatory laminin chains and this strategy has been used to boost the phenotype of laminin $\alpha 2$ chain-deficient mice (Moll et al., 2001; Meinen et al., 2007; McKee et al., 2017; Reinhard et al., 2017) (mini-agrin or agrin overexpression that re-establishes connection between laminin $\alpha 4$ chain and dystroglycan; overexpression of laminin/nidogen chimeric protein that provides polymerization domain and combinatorial approach using both mini-agrin and the chimeric protein, see also section "Laminin $\alpha 2$ Chain-Deficient Mice Overexpressing Transgenes or Lacking Other Genes").

The laminin $\alpha 2$ chain receptor integrin $\alpha 7$ (forming a dimer with the $\beta 1$ subunit) is lost from the sarcolemma of laminin a2 chain-deficient muscle (Vachon et al., 1997; Hodges et al., 1997; Cohn et al., 1999; Gawlik et al., 2004, 2006b; Doe et al., 2011). Dystroglycans, on the other hand (both $\alpha$ and $\beta$ ), are 
TABLE 4 | Summary of LAMA2-CMD mice overexpressing transgenes or AAV/lentivirus.

\begin{tabular}{|c|c|c|c|c|}
\hline Approach & Transgene/AAV & Mouse model & $\begin{array}{l}\text { Muscle condition } \\
\text { and overall health }\end{array}$ & References \\
\hline \multirow{12}{*}{$\begin{array}{l}\text { Extracellular matrix and } \\
\text { receptor modulation }\end{array}$} & Laminin $\alpha 2$ & $d y^{\mathrm{W}} / d y^{\mathrm{W}}$ & Improved & Kuang et al., 1998b \\
\hline & Laminin $\alpha 1$ & $d y^{3 K} / d y^{3 K}$ & Improved & Gawlik et al., 2004, 2006a, 2018; \\
\hline & & $d y^{2 \mathrm{~J}} / d y^{2 \mathrm{~J}}$ & Improved & Gawlik and Durbeej, 2010 \\
\hline & Truncated laminin $\alpha 1$ & $d y^{3 \mathrm{~K}} / d y^{3 \mathrm{~K}}$ & Improved & Gawlik et al., 2010 \\
\hline & $\begin{array}{l}\text { AAV carrying Cas9, and } \\
\text { single-guide RNAs correcting the } \\
\text { splicing defect }\end{array}$ & $d y^{2 J} / d y^{2 J}$ & Improved & Kemaladewi et al., 2017 \\
\hline & Mini-agrin & $d y^{\mathrm{W}} / d y^{\mathrm{W}}$ & Improved & Moll et al., 2001; \\
\hline & Mini-agrin $+\alpha \mathrm{LNNd}$ & $d y^{\mathrm{W}} / d y^{\mathrm{W}}$ & Improved & Reinhard et al., 2017 \\
\hline & Agrin & $d y^{\mathrm{W}} / d y^{\mathrm{W}}$ & Improved & Meinen et al., 2007 \\
\hline & Agrin-perlecan & $d y^{\mathrm{W}} / d y^{\mathrm{W}}$ & Improved & Meinen et al., 2007 \\
\hline & $\alpha \mathrm{LNNd}$ & $d y^{2 J} / d y^{2 J}$ & Improved & McKee et al., 2017 \\
\hline & Integrin $\alpha 7$ & $d y^{\mathrm{W}} / d y^{\mathrm{W}}$ & Improved & Doe et al., 2011 \\
\hline & Galgt2/galgt2 AAV & $d y^{\mathrm{W} / d y^{\mathrm{W}}}$ & Improved & Xu et al., 2007 \\
\hline Apoptosis inhibition & $\mathrm{Bcl}-2$ & $d y^{\mathrm{W}} / d y^{\mathrm{W}}$ & Improved & Girgenrath et al., 2004 \\
\hline \multirow[t]{3}{*}{ Promoting regeneration } & IGF-1 & $d y^{\mathrm{W}} / d y^{\mathrm{W}}$ & Improved & Kumar et al., 2011 \\
\hline & IGF-1 + Bax null & $d y^{\mathrm{W}} / d y^{\mathrm{W}}$ & Improved & Yamauchi et al., 2013 \\
\hline & ADAM12 & $d y^{\mathrm{W}} / d y^{\mathrm{W}}$ & No difference & Guo et al., 2005 \\
\hline Polyamine modulation & Smox or Amd1 lentivirus & $d y^{2 J} / d y^{2 J}$ & Improved & Kemaladewi et al., 2018 \\
\hline
\end{tabular}

TABLE 5 | Summary of LAMA2-CMD mice lacking other genes.

\begin{tabular}{|c|c|c|c|c|}
\hline Approach & Deletion & Mouse model & $\begin{array}{l}\text { Muscle condition and } \\
\text { overall health }\end{array}$ & References \\
\hline \multirow{4}{*}{$\begin{array}{l}\text { Extracellular matrix and } \\
\text { receptor modulation }\end{array}$} & Integrin $\alpha 7$ & $d y^{3 \mathrm{~K}} / d y^{3 \mathrm{~K}}$ & No difference & Gawlik and Durbeej, 2015 \\
\hline & Dystrophin & $d y^{3 \mathrm{~K}} / d y^{3 \mathrm{~K}}$ & Worsened & Gawlik et al., 2014 \\
\hline & $\beta$-sarcoglycan & $d y^{3 \mathrm{~K}} / d y^{3 \mathrm{~K}}$ & Worsened & Gawlik et al., 2014 \\
\hline & Laminin $\alpha 4$ & $\begin{array}{l}d y^{3 \mathrm{~K}} / d y^{3 \mathrm{~K}} \\
d y^{2 \mathrm{~J}} / d y^{2 \mathrm{~J}}\end{array}$ & $\begin{array}{l}\text { Overall phenotype } \\
\text { worsened but skeletal } \\
\text { muscle condition } \\
\text { remains to be reported }\end{array}$ & Miner et al., 2004 \\
\hline Apoptosis inhibition & Bax & $d y \mathrm{~W} / d y \mathrm{~W}$ & Improved & Girgenrath et al., 2004 \\
\hline $\begin{array}{l}\text { Modulation } \\
\text { mitochondrial } \\
\text { permeability transition }\end{array}$ & Cyclophilin D & $d y \mathrm{~W} / d y^{\mathrm{W}}$ & Improved & Millay et al., 2008 \\
\hline $\begin{array}{l}\text { Inflammation and } \\
\text { fibrosis modulation }\end{array}$ & & $d y^{2 J} / d y^{2 J}$ & No difference & \\
\hline Muscle growth & Myostatin & $d y^{\mathrm{W}} / d y^{\mathrm{W}}$ & No difference & Li et al., 2005 \\
\hline
\end{tabular}


TABLE 6 | Summary of pharmacological approaches in LAMA2-CMD mice.

\begin{tabular}{|c|c|c|c|c|}
\hline Approach & Compound & Mouse model & $\begin{array}{l}\text { Muscle condition and } \\
\text { overall health }\end{array}$ & References \\
\hline $\begin{array}{l}\text { Extracellular matrix } \\
\text { modulation }\end{array}$ & Laminin-111 protein & $d y^{W} / d y^{W}$ & Improved & Rooney et al., 2012 \\
\hline \multirow[t]{4}{*}{ Apoptosis inhibition } & Doxycycline & $d y^{W} / d y^{W}$ & Improved & Girgenrath et al., 2009 \\
\hline & Omigapil & $d y^{W} / d y^{W}$ & Improved & Erb et al., 2009; Yu et al., 2013 \\
\hline & & $d y^{2 \mathrm{~J}} / d y^{2 \mathrm{~J}}$ & Improved & \\
\hline & $\begin{array}{l}\text { Omigapil in combination with } \\
\text { mini-agrin transgene }\end{array}$ & $d y^{W} / d y^{W}$ & Improved & Meinen et al., 2011 \\
\hline \multirow[t]{2}{*}{ Proteasome inhibition } & MG-132 & $d y^{3 \mathrm{~K}} / d y^{3 \mathrm{~K}}$ & Improved & Carmignac et al., 2011a \\
\hline & Bortezomib & $\begin{array}{l}d y^{3 K} / d y^{3 K} \\
d y^{2 J} / d y^{2 J}\end{array}$ & $\begin{array}{l}\text { Improved } \\
\text { No difference }\end{array}$ & $\begin{array}{l}\text { Korner et al., 2014; Korner and } \\
\text { Durbeej, } 2016\end{array}$ \\
\hline Autophagy inhibition & 3-methyladenine & $d y^{3 \mathrm{~K}} / d y^{3 \mathrm{~K}}$ & Improved & Carmignac et al., 2011b \\
\hline \multirow[t]{7}{*}{$\begin{array}{l}\text { Inflammation and } \\
\text { fibrosis modulation }\end{array}$} & Losartan & $\begin{array}{l}d y^{2 J} / d y^{2 \mathrm{~J}} \\
d y^{W} / d y^{\mathrm{W}}\end{array}$ & $\begin{array}{l}\text { Improved } \\
\text { Improved }\end{array}$ & $\begin{array}{l}\text { Elbaz et al., 2012; Vohra et al., } \\
2015\end{array}$ \\
\hline & Losartan derivative & $d y^{W} / d y^{W}$ & Improved & Meinen et al., 2012 \\
\hline & Losartan and IGF-1 transgene & $d y^{W} / d y^{W}$ & Improved & Accorsi et al., 2016 \\
\hline & Losartan and growth hormone & $d y^{W} / d y^{W}$ & Improved & Accorsi et al., 2016 \\
\hline & Halofuginone & $d y^{2 J} / d y^{2 J}$ & Improved & Nevo et al., 2010 \\
\hline & Glatiramer acetate & $d y^{2 J} / d y^{2 J}$ & Improved & Dadush et al., 2010 \\
\hline & Prednisolone & $d y / d y$ & Improved & Connolly et al., 2002 \\
\hline \multirow[t]{2}{*}{ Muscle growth } & Clenbuterol & $d y / d y$ & Improved & Hayes and Williams, 1998 \\
\hline & IPLEX & $d y^{W} / d y^{W} ; B a x-/-$ & Improved & Yamauchi et al., 2013 \\
\hline Calcium modulation & Caldecrin & $d y / d y$ & Improved & Tomomura et al., 2011 \\
\hline Metabolism modulation & Metformin & $d y^{2 J} / d y^{2 J}$ & Improved (in females)* & Fontes-Oliveira et al., 2018 \\
\hline $\begin{array}{l}\text { Oxidative stress } \\
\text { inhibition }\end{array}$ & $\mathrm{N}$-acetyl-L-cystein, vitamin E & $d y^{2 J} / d y^{2 J}$ & Improved & Harandi et al., 2020 \\
\hline Exon skipping & $\begin{array}{l}\text { Phosphorodiamidate morpholino } \\
\text { oligomer targeting exon } 4 \text { of Lama2 }\end{array}$ & $d y^{3 \mathrm{~K}} / d y^{3 \mathrm{~K}}$ & n.d. & Aoki et al., 2013 \\
\hline
\end{tabular}

*Some minor beneficial effects were also noted in males. n.d., not determined.

upregulated (Gawlik et al., 2006b). It is not excluded that other, yet unidentified, laminin receptors in muscle are also perturbed.

Impaired interactions between laminin $\alpha 2$ and its binding partners instigate alternations of signaling pathways. Mouse models for LAMA2-CMD have provided an excellent platform for studies of signaling events. Signaling cascades associated with apoptosis, inflammation, metabolism, regeneration, protein turnover, and fibrosis (GAPDH-Siah1-CBP/p300-p53, Akt, TGF$\beta, \mathrm{NF \kappa B}, \mathrm{p} 53$, JAK/STAT, to mention a few) have been shown to be affected in laminin $\alpha 2$ chain-deficient murine muscle (Girgenrath et al., 2004, 2009; Erb et al., 2009; Carmignac et al., 2011a,b; Kumar et al., 2011; Meinen et al., 2012; Elbaz et al., 2015; de Oliveira et al., 2014; Mehuron et al., 2014; Accorsi et al., 2015; Fontes-Oliveira et al., 2017; Gawlik et al., 2017, 2019; Nunes et al., 2017; Pasteuning-Vuhman et al., 2018; Yoon et al., 2018). Additionally, microarray, RNA-sequencing and proteomic technologies were applied to study murine LAMA2$\mathrm{CMD}$ dystrophic muscle and provided a global overview of the gene and protein expression changed upon laminin $\alpha 2$ chaindeficiency (van Lunteren et al., 2006; Hager et al., 2008; de Oliveira et al., 2014; Kemaladewi et al., 2017; Moreira Soares Oliveira et al., 2018; Yanay et al., 2019). Such findings are essential to capitalize on opportunities given by preclinical studies and advance toward treatment design.
Analysis of cellular events in dystrophic muscle comes hand in hand with the studies of molecular interactions. A lot of attention has been given to regeneration and cells that could repair damaged muscle (satellite cells, myoblasts, non-muscle cells with myogenic potential). The subset of proliferating pro-regenerative cells has been shown to be diminished in $d y^{\mathrm{W}} / d y^{\mathrm{W}}$ muscle (Girgenrath et al., 2005), resulting in myogenesis impairment and differentiation delay in laminin $\alpha 2$ chain-deficient muscle (Kuang et al., 1999; Kumar et al., 2011; Mehuron et al., 2014). Consequently, cell therapy approaches have been implemented in $d y / d y, d y^{\mathrm{W}} / d y^{\mathrm{W}}$, and $d y^{3 \mathrm{~K}} / d y^{3 \mathrm{~K}}$ mice to support muscle renewal (myoblast, bone marrow and CD90-positive cells transplantation, manipulated mesoangioblasts) (Vilquin et al., 1996, 1999; Hagiwara et al., 2006; Fukada et al., 2008; Domi et al., 2015). Further studies exploring the properties of adult stem cells in laminin $\alpha 2$ chain-deficient muscular dystrophy are warranted, especially in the light of the enormous impact of the basement membranes on the stem cell niche remodeling in muscle (Rayagiri et al., 2018).

Muscle regeneration, inflammation and fibrosis are tightly connected in muscular dystrophy and this venue has, to some extent, been explored in mouse models for LAMA2-CMD. There is a thin line between correct tissue repair and uncontrolled fibrosis. It is all about "getting the balance right" and the 
balancing factor is inflammation (Perdiguero et al., 2012; Kharraz et al., 2013; Serrano and Munoz-Canoves, 2017). Since fibrosis is a signature of LAMA2-CMD (Mrak, 1998; Voit and Tome, 2004; Elbaz et al., 2012; Mehuron et al., 2014; Accorsi et al., 2015), inflammation should take a central spot in aiming at disease prevention. Yet, not that much is known about the inflammatory response in LAMA2-CMD, but probably it is crucial for the initial wave of muscle repair (Gawlik et al., 2017, 2019). Monocytes, macrophages and neutrophils, the elements of innate immune response, constitute inflammatory infiltrates at the site of muscle damage in laminin $\alpha 2$ chain mutants (Connolly et al., 2002; Kumar et al., 2011; Wardrop and Dominov, 2011; Meinen et al., 2012; Gawlik et al., 2017). Also, cytokines de-regulation has been demonstrated in laminin $\alpha 2$ chain-deficient murine muscle (Wardrop and Dominov, 2011; Gawlik et al., 2017). Much less is known about adaptive immunity and role of lymphocytes in laminin $\alpha 2$ chain-deficiency, although a few $\mathrm{T}$ lymphocytes have been identified in laminin $\alpha 2$ chain-deficient muscle (Rooney et al., 2012). Even if fibrosis has a destructive impact on condition of dystrophic muscle, myofibroblasts and fibroblasts have not been studied in LAMA2-CMD mouse models.

In summary, more effort should be dedicated to decipher interactions between cells involved in muscle regeneration, inflammation and fibrosis in LAMA2-CMD mouse models. Such studies could provide answers to mechanisms of human pathology and identify molecular targets for therapy of muscle wasting diseases.

\section{Laminin $\alpha 2$ Chain-Deficient Mice Overexpressing Transgenes or Lacking Other Genes}

The different LAMA2-CMD mouse models have been vital tools for the identification of disease driving mechanisms and for developing therapeutic approaches. $D y / d y, d y^{2 \mathrm{~J}} / d y^{2 \mathrm{~J}}, d y^{\mathrm{W}} / d y^{\mathrm{W}}$, and $d y^{3 \mathrm{~K}} / d y^{3 \mathrm{~K}}$ mice have been genetically manipulated to overexpress or knockout specific genes that were hypothesized to impact disease pathogenesis or serve as suitable therapy candidates (Tables 4, 5). Moreover, successful gene editing by CRISPR-Cas9 has been performed to correct the splicing defect in $d y^{2 \mathrm{~J}} / d y^{2 \mathrm{~J}}$ animals (Kemaladewi et al., 2017; Table 4). Correcting the primary underlying abnormality, which is loss of laminin $\alpha 2$ chain, and amending the subsequent disruption of the linkage between the basement membrane and the cytoskeleton, is probably the most attractive therapeutic goal for LAMA2-CMD. Consequently, laminin $\alpha 2$ and $\alpha 1$ transgenes, respectively, have been overexpressed in $d y^{\mathrm{W}} / d y^{\mathrm{W}}, d y^{3 \mathrm{~K}} / d y^{3 \mathrm{~K}}$, and $d y^{2 \mathrm{~J}} / d y^{2 \mathrm{~J}}$ mice, conferring excellent amelioration of the dystrophic phenotype (Kuang et al., 1998b; Gawlik and Durbeej, 2010; Gawlik et al., 2004, 2018; Table 4). More recently, overexpression of laminin $\alpha 1$ chain in $d y^{2 \mathrm{~J}} / d y^{2 \mathrm{~J}}$ mice was achieved with an adenoassociated virus carrying a catalytically inactive Cas9 with VP64 transactivators and single guide RNAs that target the Lama1 promoter (Kemaladewi et al., 2019; Table 4).

The primary defect of the disease was also targeted through clever molecular strategies that aimed at restoring the linkage between the extracellular matrix and cytoskeleton without the necessity of introducing the whole laminin $\alpha 2$ or $\alpha 1$ chain.
Transgenic or AVV-mediated overexpression of mini-agrin alone (Moll et al., 2001; Qiao et al., 2005) or in particular mini-agrin transgene in combination with $\alpha \mathrm{LNNd}$ transgene (a laminin/nidogen chimeric protein) (Reinhard et al., 2017) resulted in superb skeletal muscle restoration in $d y^{\mathrm{W}} / d y^{\mathrm{W}}$ mice (Table 4). Mini-agrin together with the anti-apoptotic $\mathrm{Bcl}-2$ transgene also profoundly reduced muscular dystrophy in $d y^{\mathrm{W}} / d y^{\mathrm{W}}$ mice (Meinen et al., 2011; Table 4). Moreover, mini-agrin overexpression has been evaluated in $d y^{3 \mathrm{~K}} / d y^{3 \mathrm{~K}}$ mice (very good muscle restoration) (Bentzinger et al., 2005) but not the more attractive combination of mini-agrin and $\alpha \mathrm{LNNd}$. Additionally, $\alpha \mathrm{LNNd}$ overexpression alone was shown to correct muscular dystrophy in $d y^{2 \mathrm{~J}} / d y^{2 \mathrm{~J}}$ animals (McKee et al., 2017; Table 4).

$\mathrm{Xu}$ et al. (2007) tested another way to modulate the extracellular matrix in $d y^{\mathrm{W}} / d y^{\mathrm{W}}$ mice. Cytotoxic T cell GalNAc transferase is an acetylgalactosaminyl-transferase that creates a CT-carbohydrate on selected glycoproteins and glycolipids. When overexpressed extrasynaptically in $d y^{\mathrm{W}} / d y^{\mathrm{W}}$ muscle, muscular dystrophy was reduced (Table 4).

Genetic manipulations have also been used to evaluate the roles of the laminin $\alpha 2$ chain receptor integrin $\alpha 7$ and the members of the dystrophin-glycoprotein complex (DGC) in the LAMA2-CMD disease pathology in the different mouse models. Overexpression of integrin $\alpha 7$ (that is absent from the sarcolemma in LAMA2-CMD muscle) reduced muscular dystrophy in $d y^{\mathrm{W}} / d y^{\mathrm{W}}$ mice (Doe et al., 2011; Table 4). Deletion of integrin $\alpha 7$, on the other hand, did not aggravate the disease symptoms in $d y^{3 \mathrm{~K}} / d y^{3 \mathrm{~K}}$ mice, indicating that laminin $\alpha 2$ chain and integrin $\alpha 7$ have complementary functions in skeletal muscle (Gawlik and Durbeej, 2015; Table 5). In contrast, deficiency of dystrophin and $\beta$-sarcoglycan, respectively, severely worsened the phenotype of $d y^{3 \mathrm{~K}} / d y^{3 \mathrm{~K}}$ mice (Gawlik et al., 2014; Table 5). These results suggested non redundant roles of laminin $\alpha 2$ and the DGC and a key impact of laminin-DGC axis on muscle homeostasis. At the same time, studies with $d y^{3 \mathrm{~K}} / d y^{3 \mathrm{~K}}$ mice overexpressing laminin $\alpha 1$ chain with preserved integrin $\alpha 7$ binding domains but lacking dystroglycan binding sites emphasized the significance of both linkages in rescuing the dystrophic phenotype in muscle (Gawlik et al., 2010; Table 4).

As the dystrophic LAMA2-CMD pathology is very complex, a great deal of effort has been aimed at elucidating the secondary pathogenic mechanisms. For example, augmented apoptosis, proteasomal activity and autophagy as well as impaired mitochondrial function, excessive inflammation and pathological fibrosis are all major disease drivers in LAMA2-CMD (see also section "Cellular and Molecular Events in Murine Laminin $\alpha 2$ Chain-Deficient Muscle"). Accordingly, genetic approaches that target some of these secondary pathologies have been assessed in the different mouse models. Both transgenic overexpression of the anti-apoptotic protein $\mathrm{Bcl} 2$ and deletion of the proapoptotic protein Bax reduced muscular dystrophy in $d y^{\mathrm{W}} / d y^{\mathrm{W}}$ mice (Girgenrath et al., 2004; Tables 4, 5) and removal of the mitochondrial calcium regulator cyclophilin $\mathrm{D}$, which regulates mitochondrial permeability transition pore, attenuated muscular dystrophy in $d y^{\mathrm{W}} / d y^{\mathrm{W}}$ mice (Millay et al., 2008; Table 5).

As LAMA2-CMD skeletal muscle is characterized by early acute inflammation and subsequent fibrosis, a few studies 
have investigated the roles of certain pro-inflammatory and pro-fibrotic molecules in disease pathogenesis. Deletion of osteopontin and galectin-3 (both involved in inflammatory and fibrotic processes), respectively, did not reduce muscle pathology in $d y^{3 \mathrm{~K}} / d y^{3 \mathrm{~K}}$ mouse. In fact, removal of osteopontin slightly worsened the phenotype indicating that osteopontin might be a beneficial immunomodulator in LAMA2-CMD (Gawlik et al., 2017). Similarly, absence of pro-fibrotic miR-21 in $d y^{3 \mathrm{~K}} / d y^{3 \mathrm{~K}}$ and $d y^{2 \mathrm{~J}} d y^{2 \mathrm{~J}}$ mice did not improve muscular dystrophy (Moreira Soares Oliveira et al., 2017). Complement 3-deficiency, on the other hand, prolonged survival in $d y / d y$ mice (Connolly et al., 2002; Table 5). Although genetic manipulations of osteopontin, galectin-3 and miR-21 in LAMA2-CMD mice did not reveal any major impact on development on fibrosis, pharmacological treatment with compounds that target inflammation and fibrosis has successfully been employed in $d y^{\mathrm{W}} / d y^{\mathrm{W}}$ and $d y^{2 \mathrm{~J}} / d y^{2 \mathrm{~J}}$ mice (these compounds and other pharmacological strategies will briefly be described below in section "Pharmacological Approaches in the Mouse Models for LAMA2-CMD”).

Moreover, several attempts to boost regeneration in LAMA2CMD mouse models have been performed. For example, transgenically overexpressed IGF-1 very well improved the outcome of $d y^{\mathrm{W}} / d y^{\mathrm{W}}$ mice (Kumar et al., 2011; Table 4). In contrast, overexpression of ADAM12 or removal of myostatin, respectively, did no reduce muscular dystrophy in $d y^{\mathrm{W}} / d y^{\mathrm{W}}$ mice (Guo et al., 2005; Li et al., 2005; Tables 4, 5).

Finally, Kemaladewi et al. (2018) recently identified imbalanced polyamine metabolism in $d y^{2 \mathrm{~J}} / d y^{2 \mathrm{~J}}$ tibialis anterior muscle and developed a strategy to increase the polyamine level by lentiviral-mediated overexpression of adenosylmethionine decarboxylase (Amd1) and spermine oxidase (Smox) (Table 4).

\section{Pharmacological Approaches in the Mouse Models for LAMA2-CMD}

The genetic interventions described above are undoubtedly important for the development of therapeutic approaches for LAMA2-CMD. Yet, the translation of several of these lines of attack into clinical practice remains challenging. For this reason, a number of pharmacological approaches have been investigated in the different mouse models and could ultimately permit clinical treatment possibilities. The approaches include targeting both the primary gene deficiency as well as the secondary disease drivers. Burkin and co-workers have elegantly demonstrated that laminin-111 protein therapy reduces muscular dystrophy and improves muscle repair in $d y^{\mathrm{W}} / d y^{\mathrm{W}}$ mice (Rooney et al., 2012; Van Ry et al., 2014). Apoptosis inhibition has also been evaluated with pharmacological compounds. Doxycycline and omigapil, respectively, decreased muscle pathology in $d y^{\mathrm{W}} / d y^{\mathrm{W}}$ mice and omigapil also had beneficial effects in $d y^{2 \mathrm{~J}} / d y^{2 \mathrm{~J}}$ mice (Girgenrath et al., 2004; Erb et al., 2009; Yu et al., 2013). Similarly, proteasome inhibition with MG-132 and bortezomib, respectively, and autophagy inhibition with 3-methyladenine amended some of the pathological features in $d y^{3 \mathrm{~K}} / d y^{3 \mathrm{~K}}$ mice (Carmignac et al., 2011a,b; Korner et al., 2014). Additionally, compounds that modulate inflammation (glatiramer acetate, prednisolone) (Connolly et al., 2002; Dadush et al., 2010; Rabie et al., 2019) and anti-fibrotic compounds (halofuginone, losartan, and losartan derivative) have been shown to diminish muscle pathology in $d y / d y, d y^{2 \mathrm{~J}} / d y^{2 \mathrm{~J}}$, and $d y^{\mathrm{W}} / d y^{\mathrm{W}}$ mice (Nevo et al., 2010; Elbaz et al., 2012; Meinen et al., 2012; Vohra et al., 2015). Lastly, compounds that modulate muscle growth (clenbuterol), calcium levels (caldecrin), metabolism (metformin), oxidative stress as well as exon skipping with phosphoroamidate morpholino oligomers have all shown a positive influence on the muscle phenotype in the different LAMA2-CMD mouse models (Hayes and Williams, 1998; Tomomura et al., 2011; Aoki et al., 2013; Fontes-Oliveira et al., 2018; Harandi et al., 2020; Table 6).

Considering that many different cellular functions are dysregulated in LAMA2-CMD, there have been a few reports describing strategies that simultaneously target diverse processes. Indeed, it was demonstrated that amelioration of pathology was greater with a combination of mini-agrin and Bcl-2 transgenes than single mode therapies. Similarly, a combination of miniagrin and omigapil resulted in excellent muscle condition (Meinen et al., 2011; Tables 4, 6). Girgenrath and co-workers have also evaluated combinatorial treatment and demonstrated that a combination of IGF-1 transgene and removal of Bax profoundly ameliorated disease pathology in $d y^{\mathrm{W}} / d y^{\mathrm{W}}$ mice and so did removal of Bax in combination with systemic recombinant human IGF-1 (IPLEX) (Yamauchi et al., 2013; Tables 4-6). Moreover, a combinatorial treatment utilizing transgenic IGF1 in conjunction with losartan led to remarkable reduction of muscular dystrophy in $d y^{\mathrm{W}} / d y^{\mathrm{W}}$ mice and also growth hormone enhanced losartan treatment in $d y^{\mathrm{W}} / d y^{\mathrm{W}}$ mice (Accorsi et al., 2016; Table 6).

\section{DISCUSSION}

Mouse models for LAMA2-CMD have facilitated our understanding of the disease for over two decades. During that time the research community has tried to address important disease-related questions: from the basic phenotype description, through strategies to prevent the disorder by the most obvious transgenic means (introducing the laminin $\alpha 2$ and $\alpha 1$ transgenes) or the more sophisticated molecular manipulations (combination of engineered transgenes, genome editing with CRISPR/Cas9), through pharmacological approaches to target the disease symptoms.

We are now facing a number of questions that need to be answered in order to advance the research on LAMA2CMD. What is next? How can we use the available animal models in the best possible way? What should we focus on? Would it be justified and feasible to mimic the disease in a bigger animal? Should we increase our interest in Drosophila, nematodes, zebrafish, frogs, and newts? Indeed, Peter Currie's work in zebrafish has substantially contributed to understanding of pathogenic mechanisms of the disease (Gupta et al., 2012; Sztal et al., 2012; Hall et al., 2019; Wood et al., 2019).

Is there a need for creating additional mouse models for LAMA2-CMD? For example, mice with a tissue-specific deletion of the Lama2 gene would surely become an asset in LAMA2CMD research. Perhaps one important task would be to identify 
mutations in existing mouse models $\left(d y / d y\right.$ and $\left.d y^{6 \mathrm{~J}} / d y^{6 \mathrm{~J}}\right)$. Additionally, we should further explore the new methods and technologies that in a robust way contribute to reliable evaluation of preclinical treatment outcomes. For example, magnetic resonance imaging, electrical impendence myography and identification of biomarkers could complement the classical histopathology evaluations and functional tests (Accorsi et al., 2015; Vohra et al., 2015; Moreira Soares Oliveira et al., 2018; Nichols et al., 2018).

The reproducibility of data and well-grounded comparison of outcomes are a key to good science. One of the crucial tasks that we need to dedicate more energy to is a seemingly trivial, low-status assignment to create the standard operating procedures ( $\mathrm{SOPs}$ ) for all mouse models that all researches agree upon. Another task is to... stick to them: it is still a common practice that researchers follow their own protocols despite SOPs availability. SOPs have been generated for some of the mouse models for various muscular dystrophies/muscle diseases ${ }^{4}$. Some of these protocols can be easily adapted to LAMA2-CMD mouse models (Gawlik et al., 2019). It is also encouraging that several SOPs have been described for $d y^{\mathrm{W}} / d y^{\mathrm{W}}$ mouse model ${ }^{5}$. Hence, we head toward the right direction, but the researchers in the LAMA2-CMD field need to step up and focus further on this issue. For example, SOPs for $d y^{3 \mathrm{~K}} / d y^{3 \mathrm{~K}}$ and $d y^{2 \mathrm{~J}} / d y^{2 \mathrm{~J}}$ mouse models should be created.

Variability in growth rates and overall survival of $d y^{\mathrm{W}} / d y^{\mathrm{W}}$ animals from different laboratories have been noted (Willmann et al., 2017) and such discrepancies are likely to occur for the other mouse models as well. Therefore, it may be highly relevant to replicate the different therapeutic strategies in different mouse models and in different laboratories (even though such studies will be difficult to publish). It is also essential to thoroughly analyze the onset of pathological features in the variety of muscles in LAMA2-CMD mouse models in order to choose optimal timepoints for preclinical interventions (despite the fact that most patients today may not be treated before the disease onset in the corresponding clinical set up) and select the most relevant muscles for treatment evaluation.

Thus far we face an incomplete picture of pathology in different muscle types. Considering that only in the hind limb and pelvis of a mouse there are 39 muscles (Charles et al., 2016), very few muscles have been analyzed in LAMA2-mouse models. What is more, only selected dystrophic features (for example, only fibrosis) and a limited range of time-points have been described in most publications (see references in Tables 4-6). Therefore, assessments of muscle phenotypes lack a quantitative aspect and are often based on general morphology and a researcher's perception. Again, potential studies that aim at filling those gaps do not align with current publishing and funding policies. As a result, they are rarely prioritized. Coordinated effort between different laboratories should be undertaken to focus on quantitative methods, time points and muscles of choice. In general, natural history studies, standardization of outcome

\footnotetext{
${ }^{4}$ https://treat-nmd.org/research-overview/preclinical-research/

${ }^{5}$ https://treat-nmd.org/research-overview/preclinical-research/sops-for- $\mathrm{cmd}$ animal-models/
}

measures, reporting of negative findings and importance of data validation should be further emphasized. Notably, the researchers are not on their own in these efforts. Patients' organizations (for example, Cure $\mathrm{CMD}^{6}$ ) understand the significance of such studies and greatly support basic research.

Exploring treatment strategies in a preclinical setup is a challenging and attractive goal for scientists that work with animal models. However, it has become clear that deeper understanding of pathogenic mechanisms underlying the disease development needs to be focused on. In particular, signaling pathways and involvement of different cell types in LAMA2CMD pathology could be crucial for therapy design. Apart from well-known abnormalities in the central and peripheral nervous system (that are manifested both in LAMA2-CMD patients and mouse models) (Chun et al., 2003; Quijano-Roy et al., 2012; Bönnemann and Voermans, 2012; Bonnemann et al., 2014; Menezes et al., 2014), more subtle extramuscular defects are evident in mice (e.g., hearing loss, impaired spermatogenesis, and aberrant development of thymocytes and odontoblasts) (Magner et al., 2000; Pillers et al., 2002; Yuasa et al., 2004; Hager et al., 2005). These aspects of LAMA2-CMD together with the central nervous system manifestations have been poorly studied. Similarly, other tissues that normally express laminin $\alpha 2$ chain (heart, smooth muscle) have not been fully evaluated.

Altogether, animal models are an attractive platform to investigate the variety of the disease symptoms and treatment strategies. Nevertheless, it is important to bear in mind that relatively few preclinical findings will be successfully translated to humans as mice do not always truthfully model human disease pathology. This diminishes the predictive value of animalbased discoveries for future clinical studies (Gawlik, 2018). But if only one sole finding is positively verified and could be implemented in humans, it would be a huge achievement. It all boils down to cumulated effort to properly validate preclinical results and carefully choose targets for clinical trials. That is especially important for LAMA2-CMD where a limited pool of patients for clinical test is available. The takehome message is that we have to keep going: even if the alternatives for animal research become more and more useful (induced pluripotent stem cells, human cell-based assays), they suffer from various limitations: they cannot mimic multiple interactions between various tissues, organs and immune system. In addition, pharmacokinetic/pharmacodynamic modeling is not feasible using these methods. Consequently, they are not robust enough to provide reliable verification platform for such a complex disease. Hence, the mouse models still offer the best chance for important discoveries and preclinical studies for muscular dystrophies like LAMA2-CMD will certainly remain fully dependent on animals.

\section{CONCLUSION}

In summary, we believe that research opportunities on the mouse models for LAMA2-CMD will continue to inspire us,

\footnotetext{
${ }^{6}$ www.curecmd.org
} 
scientists, and spur our joint effort to design effective treatment for the disease.

\section{AUTHOR CONTRIBUTIONS}

KG and MD wrote the manuscript and secured funding.

\section{FUNDING}

This work was generously supported by the Anna and Edwin Berger Foundation, Crafoord Foundation, Olle Engkvist Byggmästare Foundation, Royal Physiographic Society in Lund, and The Swedish Research Council and Österlund Foundation.

\section{REFERENCES}

Accorsi, A., Kumar, A., Rhee, Y., and Miller, A. (2016). IGF-1/GH axis enhances losartan treatment in Lama2-related muscular dystrophy. Hum. Mol. Genet. 25, 4624-4634. doi: 10.1093/hmg/ddw291

Accorsi, A., Mehuron, T., Kumar, A., and Rhee, Y. (2015). Integrin dysregulation as a possible driver of matrix remodeling in Laminin-deficient congenital muscular dystrophy (MDC1A). J. Neuromuscul Dis. 2, 51-61. doi: 10.3233/jnd140042

Aoki, Y., Nagata, T., Yokota, T., Nakamura, A., Wood, M. J., Partridge, T., et al. (2013). Highly efficient in vivo delivery of PMO into regenerating myotubes and rescue in laminin-alpha2 chain-null congenital muscular dystrophy mice. Hum. Mol. Genet. 22, 4914-4928. doi: 10.1093/hmg/ddt341

Bentzinger, C. F., Barzaghi, P., Lin, S., and Ruegg, M. A. (2005). Overexpression of mini-agrin in skeletal muscle increases muscle integrity and regenerative capacity in laminin-alpha2-deficient mice. FASEB J. 19, 934-942. doi: 10.1096/ fj.04-3376com

Besse, S., Allamand, V., Vilquin, J. T., Li, Z., Poirier, C., and Vignier, N. (2003). Spontaneous muscular dystrophy caused by a retrotransposal insertion in the mouse laminin alpha2 chain gene. Neuromuscul. Disord. 13, 216-222. doi: 10.1016/s0960-8966(02)00278-x

Bönnemann, C. G., and Voermans, N. C. (2012). ECM-Related Myopathies and Muscular Dystrophies. Muscle: Fundamental Biology and Mechanisms of Disease. Cambridge, MA: Academic Press.

Bonnemann, C. G., Wang, C. H., Quijano-Roy, S., Deconinck, N., Bertini, E., and Ferreiro, A. (2014). Diagnostic approach to the congenital muscular dystrophies. Neuromuscul. Disord. 24, 289-311. doi: 10.1016/j.nmd.2013. 12.011

Carmignac, V., Quere, R., and Durbeej, M. (2011a). Proteasome inhibition improves the muscle of laminin alpha2 chain-deficient mice. Hum. Mol. Genet. 20, 541-552. doi: 10.1093/hmg/ddq499

Carmignac, V., Svensson, M., Korner, Z., Elowsson, L., Matsumura, C., and Gawlik, K. I. (2011b). Autophagy is increased in laminin alpha2 chain-deficient muscle and its inhibition improves muscle morphology in a mouse model of MDC1A. Hum. Mol. Genet. 20, 4891-4902. doi: 10.1093/hmg/ddr427

Charles, J. P., Cappellari, O., Spence, A. J., Hutchinson, J. R., and Wells, D. J. (2016). Musculoskeletal geometry. PLoS One 11:e0147669. doi: 10.1371/journal.pone. 0147669

Chun, S. J., Rasband, M. N., Sidman, R. L., and Habib, A. A. (2003). Integrin-linked kinase is required for laminin-2-induced oligodendrocyte cell spreading and CNS myelination. J. Cell Biol. 163, 397-408. doi: 10.1083/jcb.200304154

Cohn, R. D., Mayer, U., Saher, G., Herrmann, R., van der Flier, A., and Sonnenberg, A. (1999). Secondary reduction of alpha7B integrin in laminin alpha2 deficient congenital muscular dystrophy supports an additional transmembrane link in skeletal muscle. J. Neurol. Sci. 163, 140-152. doi: 10.1016/s0022-510x(99) 00012-x

\section{ACKNOWLEDGMENTS}

We would like to thank Dr. Judith Reinhard, Prof. Markus Rüegg, Christina Bates, and Prof. Dean Burkin for various photos of $d y^{\mathrm{W}} / d y^{\mathrm{W}}$ mice. We apologize to colleagues whose work we did not cite due to unintentional omission.

\section{SUPPLEMENTARY MATERIAL}

The Supplementary Material for this article can be found online at: https://www.frontiersin.org/articles/10.3389/fnmol. 2020.00059/full\#supplementary-material

VIDEO S1 | A 3-week-old $d y^{3 K} / d y^{3 K}$ mouse and a wild-type littermate. The $d y^{3 K} / d y^{3 K}$ mouse is not active when placed in a new cage.

Colognato, H., and Yurchenco, P. D. (1999). The laminin alpha2 expressed by dystrophic dy(2J) mice is defective in its ability to form polymers. Curr. Biol. 9, 1327-1330. doi: 10.1016/s0960-9822(00)80056-1

Connolly, A. M., Keeling, R. M., Mehta, S., and Pestronk, A. (2001). Three mouse models of muscular dystrophy: the natural history of strength and fatigue in dystrophin-, dystrophin/ utrophin-, and laminin alpha2-deficient mice. Neuromuscul. Disord. 11, 703-712. doi: 10.1016/s0960-8966(01)00232-2

Connolly, A. M., Keeling, R. M., Streif, E. M., and Pestronk, A. (2002). Complement 3 deficiency and oral prednisolone improve strength and prolong survival of laminin alpha2-deficient mice. J. Neuroimmunol. 127, 80-87. doi: 10.1016/ s0165-5728(02)00104-2

Dadush, O., Aga-Mizrachi, S., Ettinger, K., Tabakman, R., Elbaz, M., and Fellig, Y. (2010). Improved muscle strength and mobility in the dy(2J)/dy(2J) mouse with merosin deficient congenital muscular dystrophy treated with Glatiramer acetate. Neuromuscul. Disord. 20, 267-272. doi: 10.1016/j.nmd.2010.02.002

de Oliveira, B. M., Matsumura, C. Y., Fontes-Oliveira, C. C., Gawlik, K. I., Acosta, H., Wernhoff, P., et al. (2014). Quantitative proteomic analysis reveals metabolic alterations, calcium dysregulation, and increased expression of extracellular matrix proteins in laminin alpha2 chain-deficient muscle. Mol. Cell Proteomics 13, 3001-3013. doi: 10.1074/mcp.M113.032276

Doe, J. A., Wuebbles, R. D., Allred, E. T., Rooney, J. E., and Elorza, M. (2011). Transgenic overexpression of the alpha7 integrin reduces muscle pathology and improves viability in the $\mathrm{dy}(\mathrm{W})$ mouse model of merosin-deficient congenital muscular dystrophy type 1A. J. Cell Sci. 124(Pt 13), 2287-2297. doi: 10.1242/jcs. 083311

Domi, T., Porrello, E., Velardo, D., Capotondo, A., Biffi, A., and Tonlorenzi, R. (2015). Mesoangioblast delivery of miniagrin ameliorates murine model of merosin-deficient congenital muscular dystrophy type 1A. Skelet Muscle 5:30. doi: 10.1186/s13395-015-0055-5

Elbaz, M., Yanay, N., Aga-Mizrachi, S., Brunschwig, Z., Kassis, I., and Ettinger, K. (2012). Losartan, a therapeutic candidate in congenital muscular dystrophy: studies in the dy(2J) /dy(2J) mouse. Ann. Neurol. 71, 699-708. doi: 10.1002/ana. 22694

Elbaz, M., Yanay, N., Laban, S., Rabie, M., Mitrani-Rosenbaum, S., and Nevo, Y. (2015). Life or death by NFkappaB, Losartan promotes survival in dy2J/dy2J mouse of MDC1A. Cell Death Dis. 6:e1690. doi: 10.1038/cddis.2015.60

Erb, M., Meinen, S., Barzaghi, P., Sumanovski, L. T., Courdier-Fruh, I., Ruegg, M. A., et al. (2009). Omigapil ameliorates the pathology of muscle dystrophy caused by laminin-alpha2 deficiency. J. Pharmacol. Exp. Ther. 331, 787-795. doi: 10.1124/jpet.109.160754

Ferletta, M., Kikkawa, Y., Yu, H., Talts, J. F., Durbeej, M., and Sonnenberg, A. (2003). Opposing roles of integrin alpha6Abetal and dystroglycan in lamininmediated extracellular signal-regulated kinase activation. Mol. Biol. Cell 14, 2088-2103. doi: 10.1091/mbc.e03-01-0852

Fontes-Oliveira, C. C., Soares, M., Oliveira, B., Korner, Z., and Harandi, M. (2018). Effects of metformin on congenital muscular dystrophy type 1A disease 
progression in mice: a gender impact study. Sci. Rep. 8:16302. doi: 10.1038/ s41598-018-34362-2

Fontes-Oliveira, C. C., Steinz, M., Schneiderat, P., and Mulder, H. (2017). Bioenergetic impairment in congenital muscular dystrophy type 1a and leigh syndrome muscle cells. Sci. Rep. 7:45272. doi: 10.1038/srep45272

Fukada, S., Yamamoto, Y., Segawa, M., Sakamoto, K., Nakajima, M., and Sato, M. (2008). CD90-positive cells, an additional cell population, produce laminin alpha2 upon transplantation to $\mathrm{dy}(3 \mathrm{k}) / \mathrm{dy}(3 \mathrm{k})$ mice. Exp. Cell Res. 314, 193-203. doi: 10.1016/j.yexcr.2007.09.020

Gawlik, K. I, and Durbeej, M. (2010). Transgenic overexpression of laminin alpha1 chain in laminin alpha2 chain-deficient mice rescues the disease throughout the lifespan. Muscle Nerve 42, 30-37. doi: 10.1002/mus.21616

Gawlik, K. I, and Durbeej, M. (2011). Skeletal muscle laminin and MDC1A: pathogenesis and treatment strategies. Skelet Muscle 1:9. doi: 10.1186/20445040-1-9

Gawlik, K. I, and Durbeej, M. (2015). Deletion of integrin alpha7 subunit does not aggravate the phenotype of laminin alpha2 chain-deficient mice. Sci. Rep. 5:13916. doi: $10.1038 /$ srep 13916

Gawlik, K. I, Holmberg, J., and Durbeej, M. (2014). Loss of dystrophin and beta-sarcoglycan significantly exacerbates the phenotype of laminin alpha2 chain-deficient animals. Am. J. Pathol. 184, 740-752. doi: 10.1016/j.ajpath.2013. 11.017

Gawlik, K. I, Korner, Z., Oliveira, B. M., and Durbeej, M. (2019). Early skeletal muscle pathology and disease progress in the $\mathrm{dy}(3 \mathrm{~K}) / \mathrm{dy}(3 \mathrm{~K})$ mouse model of congenital muscular dystrophy with laminin alpha2 chain-deficiency. Sci. Rep. 9:14324. doi: 10.1038/s41598-019-50550-0

Gawlik, K. I, Li, J. Y., Petersen, A., and Durbeej, M. (2006a). Laminin alpha1 chain improves laminin alpha2 chain deficient peripheral neuropathy. Hum. Mol. Genet. 15, 2690-2700. doi: 10.1093/hmg/ddl201

Gawlik, K. I., Mayer, U., Blomberg, K., Sonnenberg, A., and Ekblom, P. (2006b). Laminin alpha1 chain mediated reduction of laminin alpha 2 chain deficient muscular dystrophy involves integrin alpha7betal and dystroglycan. FEBS Lett. 580, 1759-1765. doi: 10.1016/j.febslet.2006.02.027

Gawlik, K., Miyagoe- Suzuki, Y., Ekblom, P., and Takeda, S. (2004). Laminin alpha1 chain reduces muscular dystrophy in laminin alpha2 chain deficient mice. Hum. Mol. Genet. 13, 1775-1784. doi: 10.1093/hmg/ddh190

Gawlik, K. I. (2018). At the crossroads of clinical and preclinical research for muscular dystrophy-are we closer to effective treatment for patients? Int. J. Mol. Sci. 19:1490. doi: 10.3390/ijms19051490

Gawlik, K. I., Akerlund, M., Carmignac, V., and Elamaa, H. (2010). Distinct roles for laminin globular domains in laminin alphal chain mediated rescue of murine laminin alpha2 chain deficiency. PLoS One 5:e11549. doi: 10.1371/ journal.pone.0011549

Gawlik, K. I., Harandi, V. M., Cheong, R. Y., and Petersen, A. (2018). Laminin alphal reduces muscular dystrophy in dy(2J) mice. Matrix Biol. 70, 36-49. doi: 10.1016/j.matbio.2018.02.024

Gawlik, K. I., Holmberg, J., Svensson, M., Einerborg, M., Oliveira, B. M., Deierborg, T., et al. (2017). Potent pro-inflammatory and pro-fibrotic molecules, osteopontin and galectin-3, are not major disease modulators of laminin alpha2 chain-deficient muscular dystrophy. Sci. Rep. 7:44059. doi: 10.1038/srep44059

Girgenrath, M., Beermann, M. L., Vishnudas, V. K., and Homma, S. (2009). Pathology is alleviated by doxycycline in a laminin-alpha2-null model of congenital muscular dystrophy. Ann. Neurol. 65, 47-56. doi: 10.1002/ana.21523

Girgenrath, M., Dominov, J. A., Kostek, C. A., and Miller, J. B. (2004). Inhibition of apoptosis improves outcome in a model of congenital muscular dystrophy. J. Clin. Invest 114, 1635-1639. doi: 10.1172/jci22928

Girgenrath, M., Kostek, C. A., and Miller, J. B. (2005). Diseased muscles that lack dystrophin or laminin-alpha2 have altered compositions and proliferation of mononuclear cell populations. BMC Neurol. 5:7. doi: 10.1186/1471-2377-5-7

Guo, L. T., Shelton, G. D., Wewer, U. M., and Engvall, E. (2005). ADAM12 overexpression does not improve outcome in mice with laminin alpha2deficient muscular dystrophy. Neuromuscul. Disord. 15, 786-789. doi: 10.1016/ j.nmd.2005.06.019

Guo, L. T., Zhang, X. U., Kuang, W., Xu, H., Liu, L. A., and Vilquin, J. T. (2003). Laminin alpha2 deficiency and muscular dystrophy; genotype-phenotype correlation in mutant mice. Neuromuscul. Disord. 13, 207-215.

Gupta, V. A., Kawahara, G., Myers, J. A., Chen, A. T., Hall, T. E., and Manzini, M. C. (2012). A splice site mutation in laminin-alpha2 results in a severe muscular dystrophy and growth abnormalities in zebrafish. PLoS One 7:e43794. doi: 10.1371/journal.pone.0043794

Hager, M., Bigotti, M. G., Meszaros, R., Carmignac, V., Holmberg, J., and Allamand, V. (2008). Cib2 binds integrin alpha7Bbeta1D and is reduced in laminin alpha2 chain-deficient muscular dystrophy. J. Biol. Chem. 283, 2476024769. doi: $10.1074 /$ jbc.M801166200

Hager, M., and Durbeej, M. (2009). Intrinsic laryngeal muscles are spared from degeneration in the dy $3 \mathrm{~K} /$ dy $3 \mathrm{~K}$ mouse model of congenital muscular dystrophy type 1A. Muscle Nerve 39, 91-94. doi: 10.1002/mus.21209

Hager, M., Gawlik, K., Nystrom, A., and Sasaki, T. (2005). Laminin \{alpha\}1 chain corrects male infertility caused by absence of laminin \{alpha\}2 chain. Am. J. Pathol. 167, 823-833. doi: 10.1016/s0002-9440(10)62054-8

Hagiwara, H., Ohsawa, Y., Asakura, S., Murakami, T., and Teshima, T. (2006). Bone marrow transplantation improves outcome in a mouse model of congenital muscular dystrophy. FEBS Lett. 580, 4463-4468. doi: 10.1016/j.febslet.2006. 07.015

Hall, T. E., Wood, A. J., Ehrlich, O., Li, M., Sonntag, C. S., and Cole, N. J. (2019). Cellular rescue in a zebrafish model of congenital muscular dystrophy type 1A. NPJ Regen. Med. 4:21. doi: 10.1038/s41536-019-0084-5

Harandi, V. M., Oliveira, B. M. S., Allamand, V., Friberg, A., Fontes-Oliveira, C. C., and Durbeej, M. (2020). Antioxidants reduce muscular dystrophy in the $d y^{2 J} / d y^{2 J}$ mouse model of laminin $\alpha 2$ chain-deficient muscular dystrophy. Antioxidants (Basel) 9:E244. doi: 10.3390/antiox9030244

Hayashi, Y. K., Tezak, Z., Momoi, T., Nonaka, I., Garcia, C. A., Hoffman, E. P., et al. (2001). Massive muscle cell degeneration in the early stage of merosindeficient congenital muscular dystrophy. Neuromuscul. Disord. 11, 350-359. doi: 10.1016/s0960-8966(00)00203-0

Hayes, A., and Williams, D. A. (1998). Examining potential drug therapies for muscular dystrophy utilising the dy/dy mouse: clenbuterol, I. J. Neurol. Sci. 157, 122-128. doi: 10.1016/s0022-510x(98)00084-7

Hodges, B. L., Hayashi, Y. K., Nonaka, I., Wang, W., and Arahata, K. (1997). Altered expression of the alpha7betal integrin in human and murine muscular dystrophies. J. Cell Sci. 110(Pt 22), 2873-2881.

Holmberg, J., Alajbegovic, A., Gawlik, K. I., and Elowsson, L. (2014). Laminin alpha2 chain-deficiency is associated with microRNA deregulation in skeletal muscle and plasma. Front. Aging Neurosci. 6:155. doi: 10.3389/fnagi.2014.00155

Homma, S., Beermann, M. L., and Miller, J. B. (2011). Peripheral nerve pathology, including aberrant Schwann cell differentiation, is ameliorated by doxycycline in a laminin-alpha2-deficient mouse model of congenital muscular dystrophy. Hum. Mol. Genet. 20, 2662-2672. doi: 10.1093/hmg/ddr168

Jones, K. J., Morgan, G., Johnston, H., Tobias, V., Ouvrier, R. A., Wilkinson, I., et al. (2001). The expanding phenotype of laminin alpha2 chain (merosin) abnormalities: case series and review. J. Med. Genet. 38, 649-657. doi: 10.1136/ jmg.38.10.649

Kemaladewi, D. U., Bassi, P. S., Erwood, S., Al-Basha, D., Gawlik, K. I., and Lindsay, K. (2019). A mutation-independent approach for muscular dystrophy via upregulation of a modifier gene. Nature 572, 125-130. doi: 10.1038/s41586019-1430-x

Kemaladewi, D. U., Benjamin, J. S., Hyatt, E., and Ivakine, E. A. (2018). Increased polyamines as protective disease modifiers in congenital muscular dystrophy. Hum. Mol. Genet. 27, 1905-1912. doi: 10.1093/hmg/ddy097

Kemaladewi, D. U., Maino, E., Hyatt, E., Hou, H., Ding, M., and Place, K. M. (2017). Correction of a splicing defect in a mouse model of congenital muscular dystrophy type $1 \mathrm{~A}$ using a homology-directed-repair-independent mechanism. Nat. Med. 23, 984-989. doi: 10.1038/nm.4367

Kharraz, Y., Guerra, J., Mann, C. J., and Serrano, A. L. (2013). Macrophage plasticity and the role of inflammation in skeletal muscle repair. Mediators Inflamm 2013:491497. doi: 10.1155/2013/491497

Korner, Z., and Durbeej, M. (2016). Bortezomib does not reduce muscular dystrophy in the dy2J/dy2j mouse model of laminin alpha2 Chain-deficient muscular dystrophy. PLoS One 11:e0146471. doi: 10.1371/journal.pone. 0146471

Korner, Z., Fontes-Oliveira, C. C., Holmberg, J., and Carmignac, V. (2014). Bortezomib partially improves laminin alpha2 chain-deficient muscular dystrophy. Am. J. Pathol. 184, 1518-1528. doi: 10.1016/j.ajpath.2014.01.019

Kuang, W., Xu, H., Vachon, P. H., and Engvall, E. (1998a). Disruption of the lama2 gene in embryonic stem cells: laminin alpha 2 is necessary for sustenance of mature muscle cells. Exp. Cell Res. 241, 117-125. doi: 10.1006/excr.1998.4025 
Kuang, W., Xu, H., Vachon, P. H., Liu, L., Loechel, F., Wewer, U. M., et al. (1998b). Merosin-deficient congenital muscular dystrophy. Partial genetic correction in two mouse models. J. Clin. Invest 102, 844-852. doi: 10.1172/JCI3705

Kuang, W., Xu, H., Vilquin, J. T., and Engvall, E. (1999). Activation of the lama2 gene in muscle regeneration: abortive regeneration in laminin alpha2deficiency. Lab Invest 79, 1601-1613.

Kumar, A., Yamauchi, J., Girgenrath, T., and Girgenrath, M. (2011). Musclespecific expression of insulin-like growth factor 1 improves outcome in Lama2Dy-w mice, a model for congenital muscular dystrophy type 1A. Hum. Mol. Genet. 20, 2333-2343. doi: 10.1093/hmg/ddr126

Li, Z. F., Shelton, G. D., and Engvall, E. (2005). Elimination of myostatin does not combat muscular dystrophy in dy mice but increases postnatal lethality. Am. J. Pathol. 166, 491-497. doi: 10.1016/S0002-9440(10)62271-7

Magner, W. J., Chang, A. C., Owens, J., Hong, M. J., and Brooks, A. (2000). Aberrant development of thymocytes in mice lacking laminin-2. Dev. Immunol. 7, 179-193. doi: 10.1155/2000/90943

Matsumura, K., Yamada, H., Saito, F., and Sunada, Y. (1997). Peripheral nerve involvement in merosin-deficient congenital muscular dystrophy and dy mouse. Neuromuscul. Disord. 7, 7-12. doi: 10.1016/s0960-8966(96)00402-6

McKee, K. K., Crosson, S. C., Meinen, S., Reinhard, J. R., and Ruegg, M. A. (2017). Chimeric protein repair of laminin polymerization ameliorates muscular dystrophy phenotype. J. Clin. Invest. 127, 1075-1089. doi: 10.1172/JCI90854

McKee, K. K., Yang, D. H., Patel, R., Chen, Z. L., Strickland, S., and Takagi, J. (2012). Schwann cell myelination requires integration of laminin activities. J. Cell Sci. 125(Pt 19), 4609-4619. doi: 10.1242/jcs.107995

Mehuron, T., Kumar, A., Duarte, L., Yamauchi, J., and Accorsi, A. (2014). Dysregulation of matricellular proteins is an early signature of pathology in laminin-deficient muscular dystrophy. Skelet Muscle 4:14. doi: 10.1186/20445040-4- 14

Meinen, S., Barzaghi, P., Lin, S., and Lochmuller, H. (2007). Linker molecules between laminins and dystroglycan ameliorate laminin-alpha2-deficient muscular dystrophy at all disease stages. J. Cell Biol. 176, 979-993. doi: 10.1083/ jcb.200611152

Meinen, S., Lin, S., and Ruegg, M. A. (2012). Angiotensin II type 1 receptor antagonists alleviate muscle pathology in the mouse model for laminin-alpha2deficient congenital muscular dystrophy (MDC1A). Skelet Muscle 2:18. doi: 10.1186/2044-5040-2-18

Meinen, S., Lin, S., Thurnherr, R., Erb, M., and Meier, T. (2011). Apoptosis inhibitors and mini-agrin have additive benefits in congenital muscular dystrophy mice. EMBO Mol. Med. 3, 465-479. doi: 10.1002/emmm.201100151

Menezes, M. J., McClenahan, F. K., Leiton, C. V., Aranmolate, A., and Shan, X. (2014). The extracellular matrix protein laminin alpha2 regulates the maturation and function of the blood-brain barrier. J. Neurosci. 34, 1526015280. doi: 10.1523/JNEUROSCI.3678-13.2014

Michelson, A. M., Russell, E. S., and Harman, P. J. (1955). dystrophia muscularis: a hereditary primary myopathy in the house mouse. Proc. Natl. Acad. Sci. U.S.A. 41, 1079-1084. doi: 10.1073/pnas.41.12.1079

Millay, D. P., Sargent, M. A., Osinska, H., Baines, C. P., Barton, E. R., and Vuagniaux, G. (2008). Genetic and pharmacologic inhibition of mitochondrialdependent necrosis attenuates muscular dystrophy. Nat. Med. 14, 442-447. doi: $10.1038 / \mathrm{nm} 1736$

Miner, J. H., Li, C., and Patton, B. L. (2004). Laminins alpha2 and alpha4 in pancreatic acinar basement membranes are required for basal receptor localization. J. Histochem. Cytochem. 52, 153-156. doi: 10.1177/ 002215540405200202

Miyagoe, Y., Hanaoka, K., Nonaka, I., and Hayasaka, M. (1997). Laminin alpha2 chain-null mutant mice by targeted disruption of the Lama2 gene: a new model of merosin (laminin 2)-deficient congenital muscular dystrophy. FEBS Lett. 415, 33-39. doi: 10.1016/s0014-5793(97)01007-7

Moll, J., Barzaghi, P., Lin, S., Bezakova, G., Lochmuller, H., and Engvall, E. (2001). An agrin minigene rescues dystrophic symptoms in a mouse model for congenital muscular dystrophy. Nature 413, 302-307. doi: 10.1038/3509 5054

Moreira Soares Oliveira, B., Durbeej, M., and Holmberg, J. (2017). Absence of microRNA-21 does not reduce muscular dystrophy in mouse models of LAMA2-CMD. PLoS One 12:e0181950. doi: 10.1371/journal.pone.0181950

Moreira Soares Oliveira, B., Gawlik, K. I, Durbeej, M., and Holmberg, J. (2018). Exploratory profiling of Urine MicroRNAs in the dy(2J)/dy(2J) mouse model of LAMA2-CMD: relation to disease progression. PLoS Curr. 27:10.
Mrak, R. E. (1998). The pathologic spectrum of merosin deficiency. J. Child Neurol. 13, 513-515. doi: 10.1177/088307389801301009

Nakagawa, M., Miyagoe-Suzuki, Y., Ikezoe, K., Miyata, Y., Nonaka, I., Harii, K., et al. (2001). Schwann cell myelination occurred without basal lamina formation in laminin alpha2 chain-null mutant (dy3K/dy3K) mice. Glia 35, 101-110. doi: 10.1002/glia.1075

Nevo, Y., Halevy, O., Genin, O., Moshe, I., Turgeman, T., and Harel, M. (2010). Fibrosis inhibition and muscle histopathology improvement in laminin-alpha2deficient mice. Muscle Nerve 42, 218-229. doi: 10.1002/mus.21706

Nguyen, Q., Lim, K. R. Q., and Yokota, T. (2019). Current understanding and treatment of cardiac and skeletal muscle pathology in laminin-alpha2 chaindeficient congenital muscular dystrophy. Appl. Clin. Genet. 12, 113-130. doi: 10.2147/TACG.S187481

Nichols, C., Jain, M. S., Meilleur, K. G., Wu, T., Collins, J., Waite, M. R., et al. (2018). Electrical impedance myography in individuals with collagen 6 and laminin $\alpha$ 2 congenital muscular dystrophy: a cross-sectional and 2-year analysis. Muscle Nerve. 57, 54-60. doi: 10.1002/mus.25629

Nissinen, M., Helbling-Leclerc, A., Zhang, X., Evangelista, T., Topaloglu, H., and Cruaud, C. (1996). Substitution of a conserved cysteine-996 in a cysteine-rich motif of the laminin alpha2-chain in congenital muscular dystrophy with partial deficiency of the protein. Am. J. Hum. Genet. 58, 1177-1184.

Nunes, A. M., Wuebbles, R. D., Sarathy, A., Fontelonga, T. M., Deries, M., Burkin, D. J., et al. (2017). Impaired fetal muscle development and JAK-STAT activation mark disease onset and progression in a mouse model for merosin-deficient congenital muscular dystrophy. Hum. Mol. Genet. 26, 2018-2033. doi: 10.1093/ hmg/ddx083

Nystrom, A., Holmblad, J., Pedrosa-Domellof, F., and Sasaki, T. (2006). Extraocular muscle is spared upon complete laminin alpha2 chain deficiency: comparative expression of laminin and integrin isoforms. Matrix Biol. 25, 382-385. doi: 10.1016/j.matbio.2006.05.001

Oliveira, J., Gruber, A., Cardoso, M., Taipa, R., Fineza, I., and Goncalves, A. (2018). LAMA2 gene mutation update: toward a more comprehensive picture of the laminin-alpha2 variome and its related phenotypes. Hum. Mutat. 39, 1314-1337. doi: 10.1002/humu.23599

Pasteuning-Vuhman, S., Putker, K., Tanganyika de Winter, J., Boertje-van der, J. W., and van Vliet, L. (2018). Natural disease history of the dy2J mouse model of laminin alpha2 (merosin)-deficient congenital muscular dystrophy. PLoS One 13:e0197388. doi: 10.1371/journal.pone.0197388

Patton, B. L., Wang, B., Tarumi, Y. S., and Seburn, K. L. (2008). A single point mutation in the LN domain of LAMA2 causes muscular dystrophy and peripheral amyelination. J. Cell Sci. 121(Pt 10), 1593-1604. doi: 10.1242/jcs. 015354

Perdiguero, E., Kharraz, Y., Serrano, A. L., and Munoz-Canoves, P. (2012). MKP1 coordinates ordered macrophage-phenotype transitions essential for stem cell-dependent tissue repair. Cell Cycle 11, 877-886. doi: 10.4161/cc.11.5.19374

Pillers, D. A., Kempton, J. B., Duncan, N. M., Pang, J., and Dwinnell, S. J. (2002). Hearing loss in the laminin-deficient dy mouse model of congenital muscular dystrophy. Mol. Genet. Metab. 76, 217-224. doi: 10.1016/s10967192(02)00039-2

Qiao, C., Dai, Y., Nikolova, V. D., and Jin, Q. (2018). Amelioration of muscle and nerve pathology in LAMA2 muscular dystrophy by AAV9-mini-agrin. Mol. Ther. Methods Clin. Dev. 9, 47-56. doi: 10.1016/j.omtm.2018.01.005

Qiao, C., Li, J., Zhu, T., Draviam, R., Watkins, S., and Ye, X. (2005). Amelioration of laminin-alpha2-deficient congenital muscular dystrophy by somatic gene transfer of miniagrin. Proc. Natl. Acad. Sci. U.S.A. 102, 11999-12004. doi: 10. 1073/pnas.0502137102

Quijano-Roy, S., Sparks, S. E., and Rutkowski, A. (2012). LAMA2-Related Muscular Dystrophy, Genereviews. Seattle, WA: University of Washington.

Rabie, M., Yanay, N., Fellig, Y., and Konikov-Rozenman, J. (2019). Improvement of motor conduction velocity in hereditary neuropathy of LAMA2-CMD dy(2J)/dy(2J) mouse model by glatiramer acetate. Clin. Neurophysiol. 130, 1988-1994. doi: 10.1016/j.clinph.2019.07.029

Rash, S. M., Wanitkin, S., Shiota, T., and Sahn, D. J. (1998). Congenital muscular dystrophy mouse model dy/dy has hypertrophic cardiomyopathy by echocardiography $\dagger$ 137. Pediatr. Res. 43:26. doi: 10.1203/00006450199804001-00158

Rayagiri, S. S., Ranaldi, D., Raven, A., Mohamad, N., Azhar, I. F., and Lefebvre, O. (2018). Basal lamina remodeling at the skeletal muscle stem cell niche mediates stem cell self-renewal. Nat. Commun. 9:1075. doi: 10.1038/s41467-018-03425-3 
Reinhard, J. R., Lin, S., McKee, K. K., Meinen, S., Crosson, S. C., Sury, M., et al. (2017). . Linker proteins restore basement membrane and correct LAMA2related muscular dystrophy in mice. Sci. Transl. Med. 9:eaal4649. doi: 10.1126/ scitranslmed.aal4649

Ringelmann, B., Roder, C., Hallmann, R., Maley, M., Davies, M., Grounds, M., et al. (1999). Expression of laminin alpha1, alpha2, alpha4, and alpha5 chains, fibronectin, and tenascin-C in skeletal muscle of dystrophic 129ReJ dy/dy mice. Exp. Cell Res. 246, 165-182. doi: 10.1006/excr.1998.4244

Rooney, J. E., Knapp, J. R., Hodges, B. L., and Wuebbles, R. D. (2012). Laminin-111 protein therapy reduces muscle pathology and improves viability of a mouse model of merosin-deficient congenital muscular dystrophy. Am. J. Pathol. 180, 1593-1602. doi: 10.1016/j.ajpath.2011.12.019

Serrano, A. L., and Munoz-Canoves, P. (2017). Fibrosis development in early-onset muscular dystrophies: mechanisms and translational implications. Semin. Cell Dev. Biol. 64, 181-190. doi: 10.1016/j.semcdb.2016.09.013

Sunada, Y., Bernier, S. M., Kozak, C. A., and Yamada, Y. (1994). Deficiency of merosin in dystrophic dy mice and genetic linkage of laminin $\mathrm{M}$ chain gene to dy locus. J. Biol. Chem. 269, 13729-13732.

Sunada, Y., Bernier, S. M., Utani, A., and Yamada, Y. (1995). Identification of a novel mutant transcript of laminin alpha 2 chain gene responsible for muscular dystrophy and dysmyelination in dy2J mice. Hum. Mol. Genet. 4, 1055-1061. doi: $10.1093 / \mathrm{hmg} / 4.6 .1055$

Sztal, T. E., Sonntag, C., Hall, T. E., and Currie, P. D. (2012). Epistatic dissection of laminin-receptor interactions in dystrophic zebrafish muscle. Hum. Mol. Genet. 21, 4718-4731. doi: 10.1093/hmg/dds312

Talts, J. F., Andac, Z., Gohring, W., and Brancaccio, A. (1999). Binding of the $\mathrm{G}$ domains of laminin alpha1 and alpha2 chains and perlecan to heparin, sulfatides, alpha-dystroglycan and several extracellular matrix proteins. EMBO J. 18, 863-870. doi: 10.1093/emboj/18.4.863

Talts, J. F., Sasaki, T., Miosge, N., Gohring, W., Mann, K., Mayne, R., et al. (2000). Structural and functional analysis of the recombinant G domain of the laminin alpha4 chain and its proteolytic processing in tissues. J. Biol. Chem. 275, 35192-35199. doi: 10.1074/jbc.M003261200

Tomomura, M., Fujii, T., Sakagami, H., and Tomomura, A. (2011). Serum calciumdecreasing factor, caldecrin, ameliorates muscular dystrophy in dy/dy mice. In Vivo 25, 157-163.

Vachon, P. H., Xu, H., Liu, L., Loechel, F., Hayashi, Y., and Arahata, K. (1997). Integrins (alpha7beta1) in muscle function and survival. Disrupted expression in merosin-deficient congenital muscular dystrophy. J. Clin. Invest 100, 18701881. doi: $10.1172 / \mathrm{JCI} 119716$

van Lunteren, E., Moyer, M., and Leahy, P. (2006). Gene expression profiling of diaphragm muscle in alpha2-laminin (merosin)-deficient dy/dy dystrophic mice. Physiol. Genomics 25, 85-95. doi: 10.1152/physiolgenomics.00226. 2005

Van Ry, P. M., Minogue, P., Hodges, B. L., and Burkin, D. J. (2014). Laminin111 improves muscle repair in a mouse model of merosin-deficient congenital muscular dystrophy. Hum. Mol. Genet. 23, 383-396. doi: 10.1093/hmg/ddt428

Vilquin, J. T., Guerette, B., Puymirat, J., Yaffe, D., Tome, F. M., and Fardeau, M. (1999). Myoblast transplantations lead to the expression of the laminin alpha 2 chain in normal and dystrophic (dy/dy) mouse muscles. Gene Ther. 6, 792-800. doi: 10.1038/sj.gt.3300889

Vilquin, J. T., Kinoshita, I., Roy, B., Goulet, M., Engvall, E., and Tome, F. (1996). Partial laminin alpha2 chain restoration in alpha2 chain-deficient dy/dy mouse by primary muscle cell culture transplantation. J. Cell Biol. 133, 185-197. doi: 10.1083/jcb.133.1.185

Vohra, R., Accorsi, A., Kumar, A., and Walter, G. (2015). Magnetic resonance imaging is sensitive to pathological amelioration in a model for laminindeficient congenital muscular dystrophy (MDC1A). PLoS One 10:e0138254. doi: 10.1371/journal.pone.0138254

Voit, T., and Tome, F. M. S. (2004). The Congenital Muscular Dystrophies.2. New York, NY: McGraw-Hill.

Wardrop, K. E., and Dominov, J. A. (2011). Proinflammatory signals and the loss of lymphatic vessel hyaluronan receptor-1 (LYVE-1) in the early pathogenesis of laminin alpha2-deficient skeletal muscle. J. Histochem. Cytochem. 59, 167-179. doi: 10.1369/jhc.2010.956672

Willmann, R., Gordish-Dressman, H., Meinen, S., Ruegg, M. A., Yu, Q., and Nagaraju, K. (2017). Improving reproducibility of phenotypic assessments in the DyW mouse model of laminin-alpha2 related congenital muscular dystrophy. J. Neuromuscul. Dis. 4, 115-126. doi: 10.3233/JND-17 0217

Wood, A. J., Cohen, N., Joshi, V., Li, M., Costin, A., and Hersey, L. (2019). RGD inhibition of itgb1 ameliorates laminin-alpha2-deficient zebrafish fibre pathology. Hum. Mol. Genet. 28, 1403-1413. doi: 10.1093/hmg/ddy426

Xu, H., Christmas, P., Wu, X. R., and Wewer, U. M. (1994a). Defective muscle basement membrane and lack of M-laminin in the dystrophic dy/dy mouse. Proc. Natl. Acad. Sci. U.S. A. 91, 5572-5576. doi: 10.1073/pnas.91.12.5572

Xu, H., Wu, X. R., Wewer, U. M., and Engvall, E. (1994b). Murine muscular dystrophy caused by a mutation in the laminin alpha 2 (Lama2) gene. Nat. Genet. 8, 297-302. doi: 10.1038/ng1194-297

Xu, R., Chandrasekharan, K., Yoon, J. H., and Camboni, M. (2007). Overexpression of the cytotoxic T cell (CT) carbohydrate inhibits muscular dystrophy in the dyW mouse model of congenital muscular dystrophy 1A. Am. J. Pathol. 171, 181-199. doi: 10.2353/ajpath.2007.060927

Yamauchi, J., Kumar, A., Duarte, L., Mehuron, T., and Girgenrath, M. (2013). Triggering regeneration and tackling apoptosis: a combinatorial approach to treating congenital muscular dystrophy type 1 A. Hum. Mol. Genet. 22, 43064317. doi: $10.1093 / \mathrm{hmg} / \mathrm{ddt} 280$

Yanay, N., Elbaz, M., Konikov-Rozenman, J., Elgavish, S., Nevo, Y., and Fellig, Y. (2019). Pax7, Pax3 and mamstr genes are involved in skeletal muscle impaired regeneration of dy2J/dy2J mouse model of lama2-CMD. Hum. Mol. Genet. 28, 3369-3390. doi: 10.1093/hmg/ddz180

Yang, D., Bierman, J., Tarumi, Y. S., Zhong, Y. P., Rangwala, R., and Proctor, T. M. (2005). Coordinate control of axon defasciculation and myelination by laminin-2 and -8. J. Cell Biol. 168, 655-666. doi: 10.1083/jcb.200411158

Yoon, S., Beermann, M. L., Yu, B., Shao, D., and Bachschmid, M. (2018). Aberrant caspase activation in laminin-alpha2-deficient human myogenic cells is mediated by p53 and sirtuin activity. J. Neuromuscul Dis. 5, 59-73. doi: 10.3233/JND-170262

Yu, Q., Sali, A., Van, J., der Meulen, Creeden, B. K., Gordish-Dressman, H., et al. (2013). Omigapil treatment decreases fibrosis and improves respiratory rate in dy(2J) mouse model of congenital muscular dystrophy. PLoS One 8:e65468. doi: 10.1371/journal.pone.0065468

Yuasa, K., Fukumoto, S., Kamasaki, Y., Yamada, A., Fukumoto, E., and Kanaoka, K. (2004). Laminin alpha2 is essential for odontoblast differentiation regulating dentin sialoprotein expression. J. Biol. Chem. 279, 10286-10292. doi: 10.1074/ jbc.M310013200

Yurchenco, P. D., Cheng, Y. S., Campbell, K., and Li, S. (2004). Loss of basement membrane, receptor and cytoskeletal lattices in a laminin-deficient muscular dystrophy. J. Cell Sci. 117(Pt 5), 735-742. doi: 10.1242/jcs.00911

Yurchenco, P. D., and Patton, B. L. (2009). Developmental and pathogenic mechanisms of basement membrane assembly. Curr. Pharm Des. 15, $1277-$ 1294. doi: 10.2174/138161209787846766

Yurchenco, P. D., McKee, K. K., Reinhard, J. R., and Ruegg, M. A. (2017). Laminindeficient muscular dystrophy: molecular pathogenesis and structural repair strategies. Matrix Biol. 71-72, 174-187. doi: 10.1016/j.matbio.2017.11.009

Conflict of Interest: The authors declare that the research was conducted in the absence of any commercial or financial relationships that could be construed as a potential conflict of interest.

Copyright (c) 2020 Gawlik and Durbeej. This is an open-access article distributed under the terms of the Creative Commons Attribution License (CC BY). The use, distribution or reproduction in other forums is permitted, provided the original author(s) and the copyright owner(s) are credited and that the original publication in this journal is cited, in accordance with accepted academic practice. No use, distribution or reproduction is permitted which does not comply with these terms. 